\title{
Systems Integration for \\ Manufacturing Applications \\ Program 1996 Annual Report
}

An intramural NIST research and standards development program applying High Performance Computing and

Communications technology to manufacturing applications.

James E. Fowler

U.S. DEPARTMENT OF COMMERCE

Technology Administration

National Institute of Standards

and Technology

Manufacturing Engineering Laboratory

Manufacturing Systems Integration Division

Gaithersburg, MD 20899-0001

$Q C$

100

NLT

.056

N0.6026

1997 



\section{Systems Integration for \\ Manufacturing Applications \\ Program 1996 Annual Report}

An intramural NIST research and standards development program applying High Performance Computing and

Communications technology to manufacturing applications.

James E. Fowler

U.S. DEPARTMENT OF COMMERCE

Technology Administration

National Institute of Standards and Technology

Manufacturing Engineering Laboratory

Manufacturing Systems Integration Division

Gaithersburg, MD 20899-0001

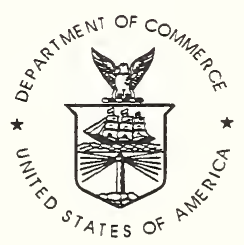

U.S. DEPARTMENT OF COMMERCE

William M. Daley, Secretary

TECHNOLOGY ADMINISTRATION

Mary L. Good, Under Secretary for Technology

NATIONAL INSTITUTE OF STANDARDS

AND TECHNOLOGY

Robert E. Hebner, Acting Director 


\section{Program Office Staff}

The SIMA Program Office is responsible for managing and compiling information for all projects supported by the SIMA Program. The SIMA Program Office staff are:

- James Fowler (Program Manager) jefowler@nist.gov

- Robert Densock (Computer Scientist) densock@cme.nist.gov

- Clarence Johnson (Program Analyst) ceejay@cme.nist.gov

- Brenda Thomasson (Secretary) blthomas@cme.nist.gov

\section{Disclaimer}

No approval or endorsement of any commercial product by the National Institute of Standards and Technology is intended or implied. Certain commercial equipment, instruments, or materials are identified in this report in order to facilitate understanding. Such identification does not imply recommendation or endorsement by the National Institute of Standards and Technology, nor does it imply that the materials or equipment identified are necessarily the best available for the purpose.

This publication was prepared by United States Government employees as part of their official duties and is, therefore, a work of the U.S. Government and not subject to copyright. 


\section{Table of Contents}

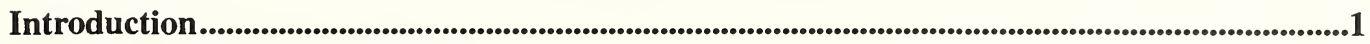

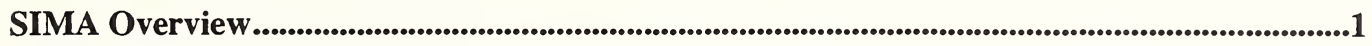

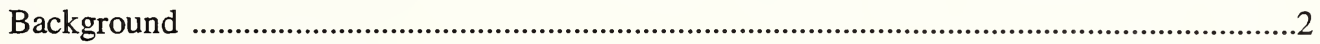

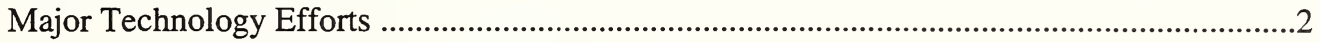

Information Interfaces: Process and Progress .........................................................................6

Project Accomplishments .................................................................................................................................111

Manufacturing Systems Environment Project Summaries ……….........................................12

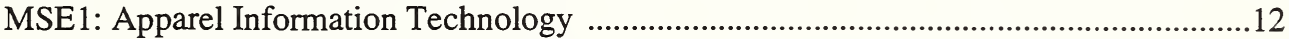

MSE2: Electronic Commerce for the Electronics Industry (ECCI) .....................................13

MSE3: Information Protocols for Design ..........................................................................15

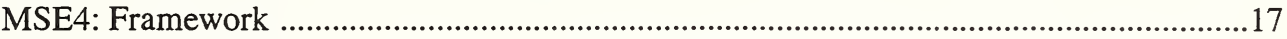

MSE5: Operator Interfaces for Virtual and Distributed Manufacturing ..............................19

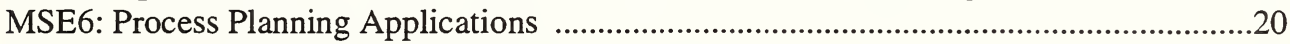

MSE7: Process Plant Engineering and Construction ……...................................................22

MSE8: Production and Product Data Management ……....................................................23

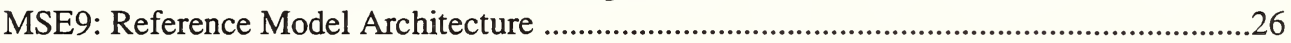

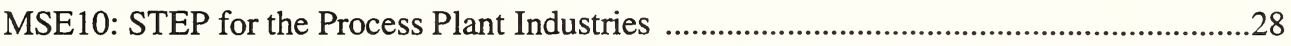

MSE11: Virtual Environments and Visualization for Manufacturing ……...........................29

Standards Development Environment Project Summaries ...................................................30

SDE1: Application Protocol Development Environment (APDE) ......................................30

SDE2: Protocol Testing for Process Plant Representations ....................................................32

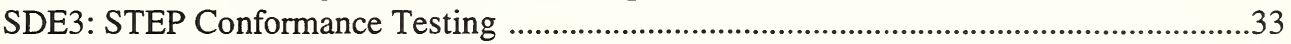

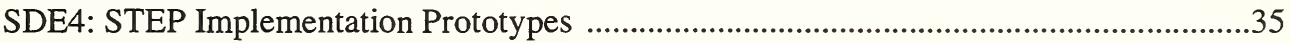

Testbeds and Technology Transfer Environment Project Summaries ......................................37

TTTE1: Advanced Manufacturing Systems and Networking Testbed .................................37

TTTE2: Analysis Tools for Assessment and Optimization of Process and Product Design 38

TTTE3: Integration of NIST Standard Reference Data into Information Networks ............39

TTTE4: NIST Informatics Web Site Supporting Advanced Ceramics Applications ...........40

TTTE5: Online Access to NIST Chemical Reference Data .................................................40

TTTE6: Standards for Exchange of Instrument Data and NIST Chemical Reference Data 40

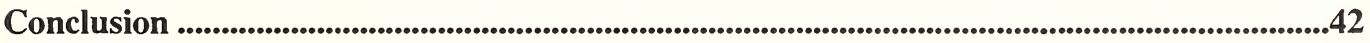

References...............................................................................................................................................................42

Appendix A: Program Organization .......................................................................................................43

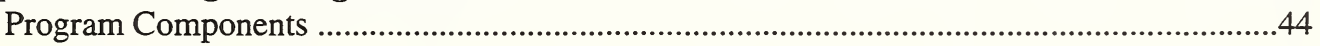

Appendix B: Collaborators .....................................................................................................................446

Consortia, National Programs, Professional and Trade Associations ......................................46

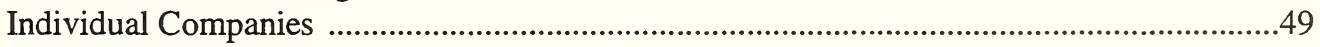

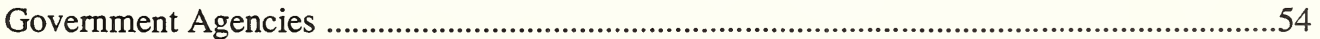

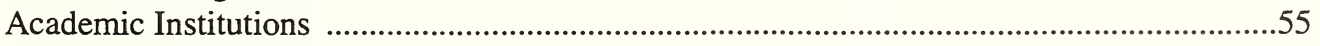

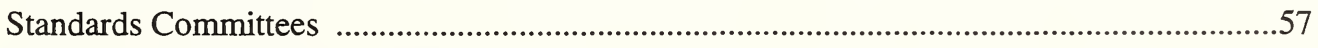

Appendix C: FY96 Project Publications ............................................................................................59

Appendix D: Program Products Newly Available in FY96 ...........................................................61 


\section{Introduction}

The Systems Integration for Manufacturing Applications (SIMA) Program is a major intramural effort being undertaken at the National Institute of Standards and Technology (NIST) to support the application of information technologies to the manufacturing domain. Initiated in 1994, the Program works with industry to develop technology solutions enabling integration of the systems used in the engineering and manufacturing of various kinds of products. The goals and supporting plans for the Program were originally described in [1] and have since been updated in [2]. Program activities and project accomplishments for the 1994 and 1995 fiscal years were documented in a report issued last year [3]. The purpose of this document is to report on the Program's technical activities for the fiscal year ended in 1996 (FY96). The intended audience for this document includes private sector organizations and federal agencies collaborating with NIST, other agencies supporting the government initiative on High Performance Computing and Communications (HPCC), and the general public. This report is available via the SIMA web page (http://www.nist.gov/sima/) or by electronic mail request to the SIMA Program office secretary (simasec@ nist.gov).

This report is organized as follows: the SIMA Overview section provides a high-level description of the Program's goals, technical efforts, results, and progress. Following that the Project Accomplishments section provides individual descriptions for each of the twenty-one projects funded by SIMA in FY96. Each project description includes a summary of the project's FY96 accomplishments along with a list of the project's collaborators. The Appendices to the report include a description of the organization of the Program (Appendix A), tables summarizing all collaborators enumerated in each of the project descriptions (Appendix $B$ ), a list of publications completed by the projects (Appendix $C$ ), and a list of products available from the projects (Appendix $D$ ).

\section{SIMA Overview}

NIST's SIMA Program is the agency's coordinating focus for its HPCC activities addressing the information interface needs of the U.S. manufacturing community. Specifically, the SIMA Program works with U.S. industry to:

- develop information exchange and interface protocol standard solutions to manufacturing integration problems,

- establish test mechanisms for validating solutions and implementations, and

- transfer information technology solutions to manufacturing enterprises.

These efforts will allow manufacturing industries to make use of the National Information Infrastructure (NII) as a mechanism for communicating product and process data among various manufacturing activities such as product/ process design, analysis, planning, scheduling, production, and quality control. Manufacturing applications require standard protocols for data exchange (information interfaces) to communicate with each other via NII technologies. The protocols evolving under the umbrella of ISO 10303 (known as the Standard for Exchange of Product Model Data or STEP [4]) are considered to be key information interfaces for the manufacturing industry. STEP is expected to accelerate the evolution of concurrent engineering, support electronic data interchange and electronic commerce, and enable business partners to share sophisticated product data representations throughout the product lifecycle. Information interfaces (like STEP) which provide scientists, engineers, and manufacturing personnel with the capability to share information among different activities, among different application software components, and across local and wide-area networks are the primary focus of the SIMA Program. 


\section{Background}

The goal of the U.S. government's High Performance Computing and Communication (HPCC) Program is to accelerate the development of future generations of high performance computers and networks and the use of these resources in the government and throughout the U.S. economy. The HPCC Program was formally established by the High Performance Computing Act of 1991 (Public Law 102-194). The four original components ${ }^{1}$ of the HPCC Program were augmented in FY9 4 with a new component known as Information Infrastructure Technology and Applications (IITA) [5]. The ITTA component supported research and development efforts that would enable integration of critical information systems and demonstrate feasible solutions to problems of national importance [6]. Twenty-first century manufacturing, i.e., advanced manufacturing processes and products, was one of the challenges to be addressed by IITA activities [7]. For FY97, the components of the HPCC Program were broadened and refocused into Program Component Areas (PCAs) [8]. These PCAs build on the foundations established in the previously identified component domains and continue to address the HPCC challenge problems. The PCAs are known as High End Computing and Computation, Large-Scale Networking, High Confidence Systems, HumanCentered Systems, and Human Resources, Education, and Training. The Human Centered Systems (HuCS) PCA which evolved from the IITA component - performs research and development making the products of computing systems and communication networks more easily accessible and useable to a wide range of user communities. Information interface issues are central to such research and development efforts.

\section{Major Technology Efforts}

SIMA technology efforts stem from the needs of U.S. manufacturers and their software suppliers. In the previous annual report, the mechanisms which the Program uses to identify those needs and to organize the Program and projects in support of those needs were discussed [3]. Industry needs evolve in response to technology and market realities, thereby resulting in appropriate changes in the SIMA Program's project portfolio over time. Twenty-one (21) projects participated in the SIMA Program in FY96. These projects addressed a wide range of industry manufacturing domains: chemical products, electrical products, materials, mechanical products, production facilities, and textile products. In addition there were projects addressing issues with respect to the development, testing, and deployment of the STEP standards. A small set of projects focused on the application and deployment of information technology solutions in support of the Program's projects as a whole. Appendix A of this document provides organizational details of the Program; in this section the focus is on the technology areas addressed in the projects.

There are two major, domain-independent categories of manufacturing activities addressed by the SIMA Program. The first is product design and engineering. These activities may include needs analysis, requirements specification, product design synthesis, analysis and validation of design solutions, along with various documentary tasks associated with these design and engineering activities. The second major category of activities addressed in SIMA is manufacturing and production engineering. These activities may include specifying production facilities needed for manufacturing of a product, specifying appropriate manufacturing processes, selecting and scheduling equipment and personnel, validating production processes against product requirements and business objectives, documentary tasks, and execution of production processes.

There is a third major category of technical effort in the SIMA Program, that being development of generic integration technologies. These are generic in the sense that they support development and execution of the technology solutions which are the focus of the two major manufacturing activities described above. They are also generic in that they can be applied to multiple problem domains. However, they are not so generic that they don't have a manufacturing context. For example, although development of new computer architectures or networking

\footnotetext{
1. High Performance Computing Systems; National Research and Education Network; Advanced Software Technology and Algorithms; Basic Research and Human Resources.
} 
technologies do fall within the HPCC purview and could be said to support the U.S. manufacturing infrastructure, such technology efforts are not a part of SIMA because it is unlikely that the solutions developed would be specific to industries' manufacturing activities.

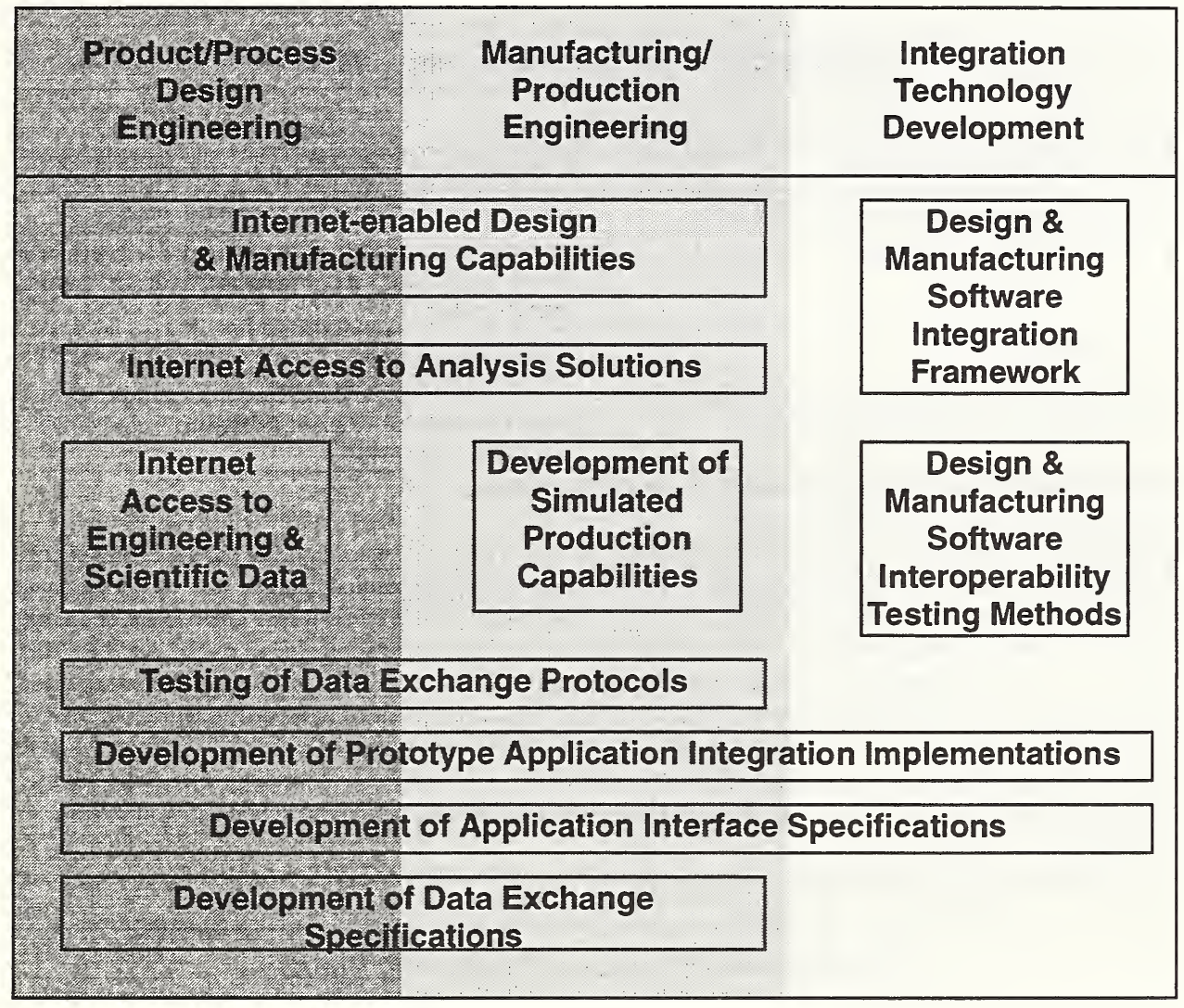

Figure 1. Major SIMA Activities

Figure 1 illustrates the relationship of the three major categories of SIMA activities to project technical efforts. Some technical efforts are specific to only one category, while others span two or more categories. Consider the "Internet Access to Engineering and Scientific Data" technical effort. The SIMA Program has a suite of projects which are working to make NIST's evaluated standard reference data available through internet browsing software thereby making it readily available on the workstations of scientists and engineers. This data is used in the development and validation of material or chemical product designs, hence the effort falls completely within the product/process design engineering activity category. The "Internet Access to Analysis Solutions" effort spans both the design and production activity categories since it is providing guidance for selection of statistical solutions as well as the computation and interpretation of statistical results. These capabilities can be used by engineers performing product design analysis as well as by manufacturing engineers investigating statistical process control problems. The Program's multiple efforts in the "Development of Application Integration Implementations" span all three major activity categories. This year has seen prototypes developed for integration of virtual assembly and design systems, integration of plant layout and simulation systems, and integration of object request broker services with engineering applications thereby covering the design, production, and integration categories. 
Looking at the categories of technical activities in more detail, we can identify specific results in each category and look at the benefits of those results. Table 1 enumerates FY96 results applicable to the Product/Process Design

\begin{tabular}{|c|c|}
\hline \multicolumn{2}{|c|}{ Product/Process Design Engineering Efforts } \\
\hline Results & Benefits \\
\hline STEP.'et Evaluation of ISO 10303-203 & Lower translator development costs for CAD vendors. \\
\hline Auto Supply Chain Deployment of ISO 10303-203 & Reduce CAD investments for automotive suppliers. \\
\hline ISO 10303-227 Vendor Prototypes & $\begin{array}{l}\text { Identify standard implementation issues for architecture/engi- } \\
\text { neering/construction CAD vendors and feedback results to } \\
\text { standards body. }\end{array}$ \\
\hline NIST Chemistry Webbook & $\begin{array}{l}\text { Chemical structure data readily available on desktop worksta- } \\
\text { tions of scientists and engineers. }\end{array}$ \\
\hline Virtual Assembly - CAD Interface Prototype & $\begin{array}{l}\text { Identify interoperability issues between virtual assembly and } \\
\text { commercial CAD systems. }\end{array}$ \\
\hline
\end{tabular}

TABLE 1. Results and Benefits in Product/Process Design Engineering

Engineering activity category. The first three results stem from the Program's work in testing of STEP data exchange protocols and development of STEP testing methods. The benefits for those results include lower development costs for the Implementors of those standards and higher reliability products for their end-users. The NIST Chemistry Webbook is one specific result from the suite of standard reference data projects mentioned earlier, and here the benefit is for chemical engineers working on development and application of new formulations. The prototype interface between virtual assembly and computer-aided design systems has helped to identify representational issues which need to be addressed to integrate these two types of systems. Manufacturers of large-scale products want to use virtual assembly capabilities for pre-production determination of assembly plans; the prototype developed this year is the first step to linking these systems with existing design systems in order to access component geometries.

Table 2 enumerates some of the Program's results applicable to the Manufacturing/Production Engineering category

\begin{tabular}{|l|l|}
\hline \multicolumn{2}{|c|}{ Manufacturing/Production Engineering Efforts } \\
\hline \multicolumn{1}{|c|}{ Results } & \multicolumn{1}{|c|}{ Benefits } \\
\hline \hline Internet-accessible Process Plan Repository & $\begin{array}{l}\text { Availability of common test data sets for validation of process } \\
\text { planning system integration efforts. }\end{array}$ \\
\hline ISO 10303-213 Vendor Prototypes & $\begin{array}{l}\text { Identify standard implementation issues for process planning } \\
\text { and NC software vendors and feedback results to standards } \\
\text { body. }\end{array}$ \\
\hline Virtual Production Facility Implementation & $\begin{array}{l}\text { Perform systems integration testing without cost of capital } \\
\text { equipment. }\end{array}$ \\
\hline Network-accessible Virtual Assembly Line Prototype & $\begin{array}{l}\text { Disseminate manufacturing process instructions to workers } \\
\text { using network and virtual reality technologies. }\end{array}$ \\
\hline $\begin{array}{l}\text { Production Scheduling - Shop Floor Data Collection Vendor } \\
\text { Prototypes }\end{array}$ & $\begin{array}{l}\text { Identify interoperability issues for production scheduling and } \\
\text { shop floor data collection software vendors. }\end{array}$ \\
\hline
\end{tabular}

TABLE 2. Results and Benefits in Manufacturing/Production Engineering

of activities. The development of an internet-accessible process plan data repository to contain design data and corresponding process plans has attracted considerable interest from developers of process planning and design systems in both industry and academia. In addition it allows users of those systems to compare capabilities of those systems using common baselines. Another process planning effort has been the testing of a STEP protocol enabling 
exchange between process planning systems and numerical control programming systems. The vendor-developed prototypes used in this testing effort are resulting in final improvements to that STEP specification in preparation for its standardization. The effort has also helped vendors address issues with respect to the specification's implementation in order to provide more robust capabilities to their customers. The initial virtual production facility developed in FY96 has provided the Program with a simulated production capability in which to test and validate multiple manufacturing application integration mechanisms. Identifying the techniques needed to use such simulation systems as a testbed for pre-production integration of both manufacturing software and hardware will benefit the many manufacturers who hope to do this type of testing before expensive capital equipment and labor is committed. In another manufacturing simulation effort, an assembly line production process was modeled for use as a mechanism to disseminate information about the assembly process to workers so as to ensure proper assembly procedures. Using multi-media techniques in conjunction with an internet-browser, the prototype allows users to view workstation operations, appropriate components, and quality checking procedures. Such technologies could be used as training aids and also as the basis for directing and modifying shop floor processes. The prototype interface between shop floor data collection and scheduling systems is another result which is identifying issues with respect to what information needs to be shared between these two types of systems. Integrating these systems allows for dynamic rescheduling in response to real-time production information. This prototype was developed with the involvement of the system vendors themselves; this early vendor involvement should lead to more rapid implementation of an interface solution and adoption of a standard.

Table 3 enumerates some of the results applicable to the Integration Technology Development category of activities.

\begin{tabular}{|l|l|}
\hline \multicolumn{2}{|c|}{ Integration Technology Development Efforts } \\
\hline \multicolumn{1}{|c|}{ Results } & \multicolumn{1}{c|}{ Benefits } \\
\hline \hline Internet-accessible ISO 10303 Testing & Provide groundwork for future web-based testing services. \\
\hline Product Data Management Interface Prototype & $\begin{array}{l}\text { Identify interoperability issues for product data management } \\
\text { and engineering/manufacturing software vendors. }\end{array}$ \\
\hline ISO 10303-26 (Standard Data Access Interface) Prototype & $\begin{array}{l}\text { Identify standard implementation issues for database and } \\
\text { engineering/manufacturing software vendors and feedback } \\
\text { results to standards body. }\end{array}$ \\
\hline Manufacturing Systems Integration Specifications Prototype & $\begin{array}{l}\text { Identify compatibility issues among multiple specifications } \\
\text { addressing distinct engineering and manufacturing system } \\
\text { activities. }\end{array}$ \\
\hline Internet-accessible ISO 10303 Specification Components & Reduce the complexity of specification development. \\
\hline
\end{tabular}

TABLE 3. Results and Benefits in Integration Technology

Providing testing mechanisms for manufacturing systems integration protocols is one of the fundamental goals of the Program. In this area the provision of the first internet-accessible conformance testing capability is a platform upon which the Program will expand. The FY96 result, testing of vendor implementations of one STEP data exchange protocol, is currently in use by numerous computer-aided design system vendors as well as their customers enabling the vendors to verify the functionality of their translators and the users to verify interoperability with other systems. The prototype product data management (PDM) system interface developed in FY96 helped explore issues relating to the interfacing of these systems to manufacturing applications as well the relationship between these systems and data exchange protocols defined in STEP. This prototype development effort occurred at a time of high industry interest in defining a standard PDM interface mechanism. Since the development of the prototype the Object Management Group has initiated their formal process for definition of an industry standard. NIST staff are supporting this industryled effort. The prototype developed for implementation of STEP's data access interface has two principal benefits the first being identification of issues with respect to implementation of the standard, and the second being initial exploration of issues with respect to testing for conformance to the proposed standard. With the number of software systems used in the manufacturing process and the number of interface specifications needed to make these individual 
software systems work together, the need to fit the individual interface specifications together coherently becomes clear. The prototype developed in FY96 did just that by selecting from existing industry specifications for equipment control, system operation, and engineering application interfaces and making them work together in a production setting. Identifying and resolving the issues to make such specifications work together is crucial to enterprise integration. The task of making multiple complex specifications work together could be easier if, during their development, common information constructs could be identified and reused. The initial version of an internetaccessible information repository containing STEP specification components is enabling that concept through an overall effor to make the process of developing STEP protocols less time-consuming and with higher quality.

A common thread throughout the three categories of SIMA activities is the development, testing, and deployment of manufacturing software application integration specifications. Given that these tasks are fundamental to many SIMA efforts, the Program has documented a process for their execution. It is called the Initial Manufacturing Exchange Specification (IMES) process [9]. The next section outlines the process along with the Program's progress with respect to IMES development.

\section{Information Interfaces: Process and Progress}

LMESs are information interfaces which can take the following forms:

- an interface specification between a human and a software application,

- an interface specification between two or more software applications, or

- a reference information repository specification.

The last IMES type refers to a specification for the contents of a repository (typically a database) which is used to provide information to many activities but the contents of which are updated by only a single process (typically an administration process).

\section{The IMES Process}

An LMES is developed through an industry review and consensus process and is accepted by the manufacturing community as a definitive solution to a particular interoperability problem. The development of an IMES involves seven phases. The execution of these phases need not occur sequentially -- some may overlap while others may occur in parallel. Figure 2 illustrates the seven phases showing how results from each phase are used by the others. The individual phases are described as follows:

\section{Phase 1: Identify/Define Industry Need}

The initial activity of LMES development is identifying and documenting an industry need, manufacturing scenario, or problem statement to define the scope and manufacturing domain of the proposed project. This need could be identified in several ways. Industrial collaborators are to be involved in defining this need.

\section{Phase 2: Analyze Requirements}

This MES development phase consists of analyzing the current situation within the manufacturing scenario to understand current capabilities, prior attempts at a solution, and specific needs that must be accommodated in the proposed IMES solution. A requirements specification is the primary desired output from this project phase. Such a specification will enable widespread industry review of the detailed requirements which a solution must satisfy in a form that is understandable by the majority of the target manufacturing community. 


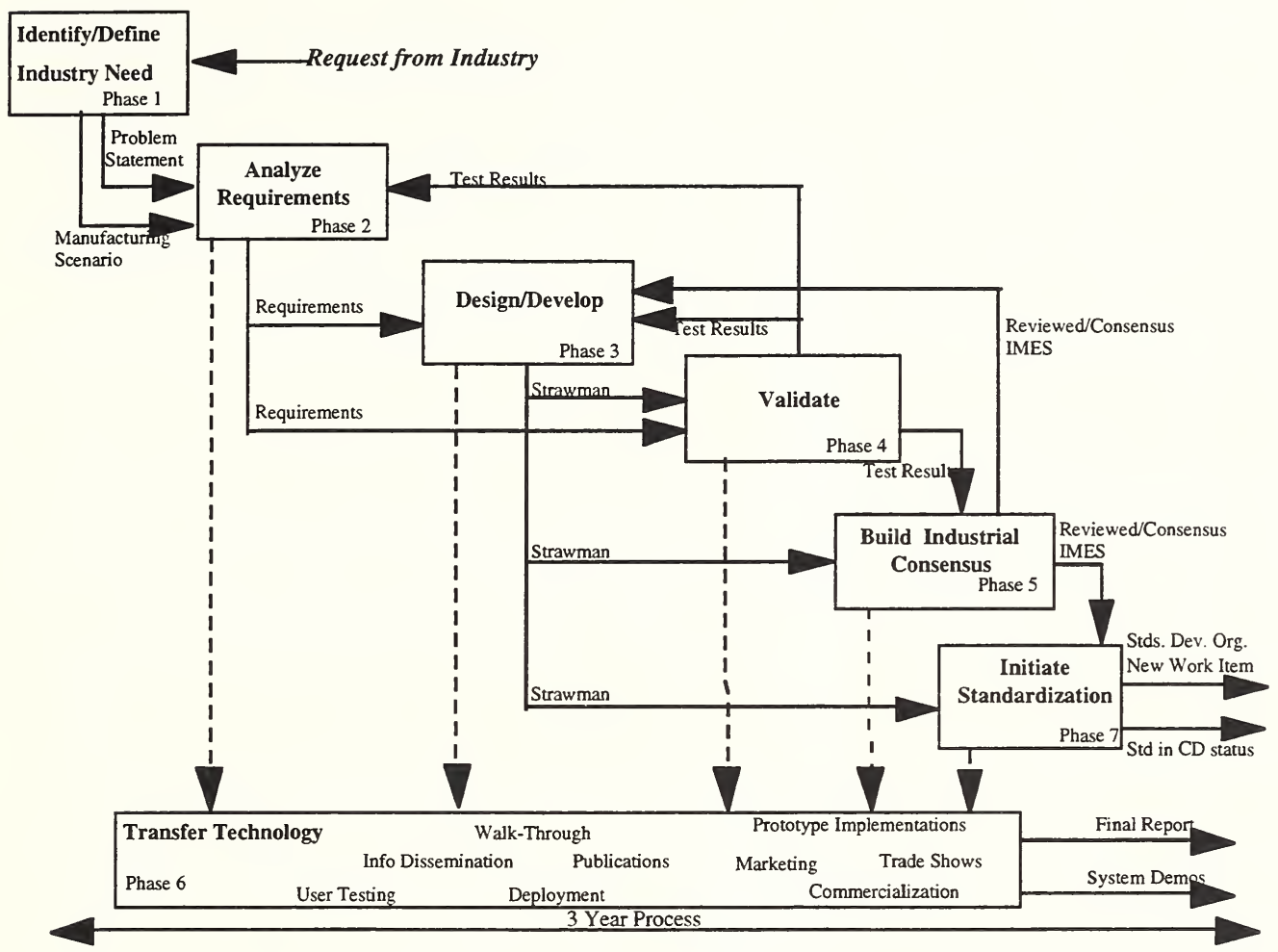

Figure 2. IMES Process Activities

Phase 3: Design/Develop

This IMES development phase consists of the actual design, development, and documentation of the proposed IMES technical solution which satisfies the requirements specified in the previous phase. The solution may consist of a combination of deliverable types, including information model(s), interface protocol(s), or process model(s), as required by the problem to be solved. The primary output of this phase is the initial version of the strawman proposal for external review.

Phase 4: Validate

A validation phase is required to ensure the completeness, validity, and usability of the proposed IMES solution. Validation activities may take several forms, including: prototype implementations, detailed walk-through with domain experts, or a comparison with known references. A proposed solution with demonstrated prototype implementations and validation test results makes a much stronger case for standardization. The documented test results (obviously based upon the prototype implementation, test environment, test suites, or other validation tools) are considered the primary output of this phase. 


\section{Phase 5: Build Consensus}

By definition, an IMES is developed from an industry consensus viewpoint. Whereas most IMES development phases require some collaboration or interaction with industrial counterparts, this phase of IMES development requires interaction with a large segment of the target manufacturing community. This interaction can be accomplished through technical workshops, user group meetings, correspondence, or site visits. IMES development projects should endeavor to obtain and accommodate as much input and feedback from industry as possible in the proposed project solution. True consensus may never be reached. This project phase is deemed necessary, however, for positioning and delivering a quality-proposed straw'man for standardization to an appropriate standards development organization. This phase is differentiated from the actual standardization process to allow and encourage other consensus-building activities without the potential constraints and procedures required by standards organizations. The primary deliverable of this phase is an updated Strawman IMES resulting from the consensus-building activities. In some cases, significant comments and suggestions may indicate the need for the project to iterate back to the IMES Design/ Develop Phase 3.

\section{Phase 6: Transfer Technology}

One of the primary missions of NIST is to provide technology transfer of NIST research results to industry. The SIMA Program supports this mission. IMES development efforts will include aspects of technology transfer to publicize, market, and transition project activities and results to industry or standards development organizations. Technology transfer should be an ongoing project activity. Various methods of technology transfer can be employed at the various stages of the IMES development effort to supply industry collaborators and the manufacturing community with current information. The primary deliverables for this phase consist of a final report and system demonstrations.

\section{Phase 7: Initiate Standardization}

Since an MMES is a proposed standard solution to a manufacturing integration need, IMES development efforts must include interaction with appropriate standards development organizations to initiate this standardization. These activities may include attending standards meetings, participating on various standards committees, or writing project correspondence with standards development organization conveners. The objective of this phase is to initiate the proposed standards work (either as a new work item or modifications to existing standards/work items) to a point where it will be self-sustaining within the standards development organization.

\section{IMES Progress}

Eight of the SIMA projects have identified a total of twenty-one IMES development efforts. In addition to those eight projects, another six projects are contributing to the development or testing of information interfaces which are already in an advanced stage of the formal standardization process (and hence are not considered IMESs). Table 4 depicts the IMESs under development and their stage of completion in the IMES process as of the end of FY96. In this table the leftmost column identifies the name of the SIMA projects and the gray bars to the right of the project name indicate each IMES being developed by that project. The length of the gray bar illustrates which IMES process phases have been addressed through FY96. The majority of the IMESs are in the initial phases of development reflecting the projects' efforts in working with industry collaborators to define the scope of the problems that can be addressed through development of these information interface specifications. The few IMESs that have completed the requirements analysis phase or have advanced beyond it are those that have had a "head-start" from pre-existing NIST and industry efforts. 


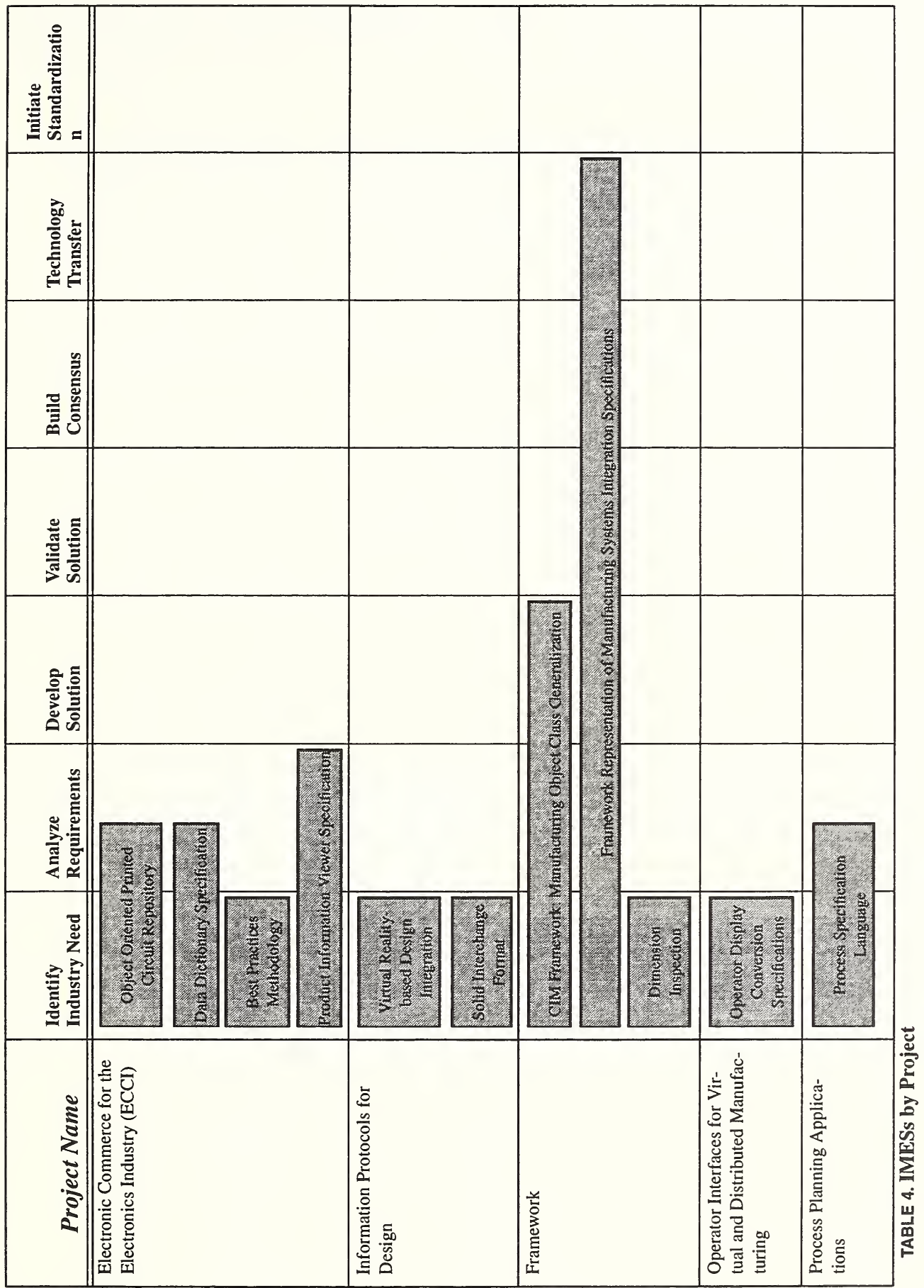


SIMA Overview

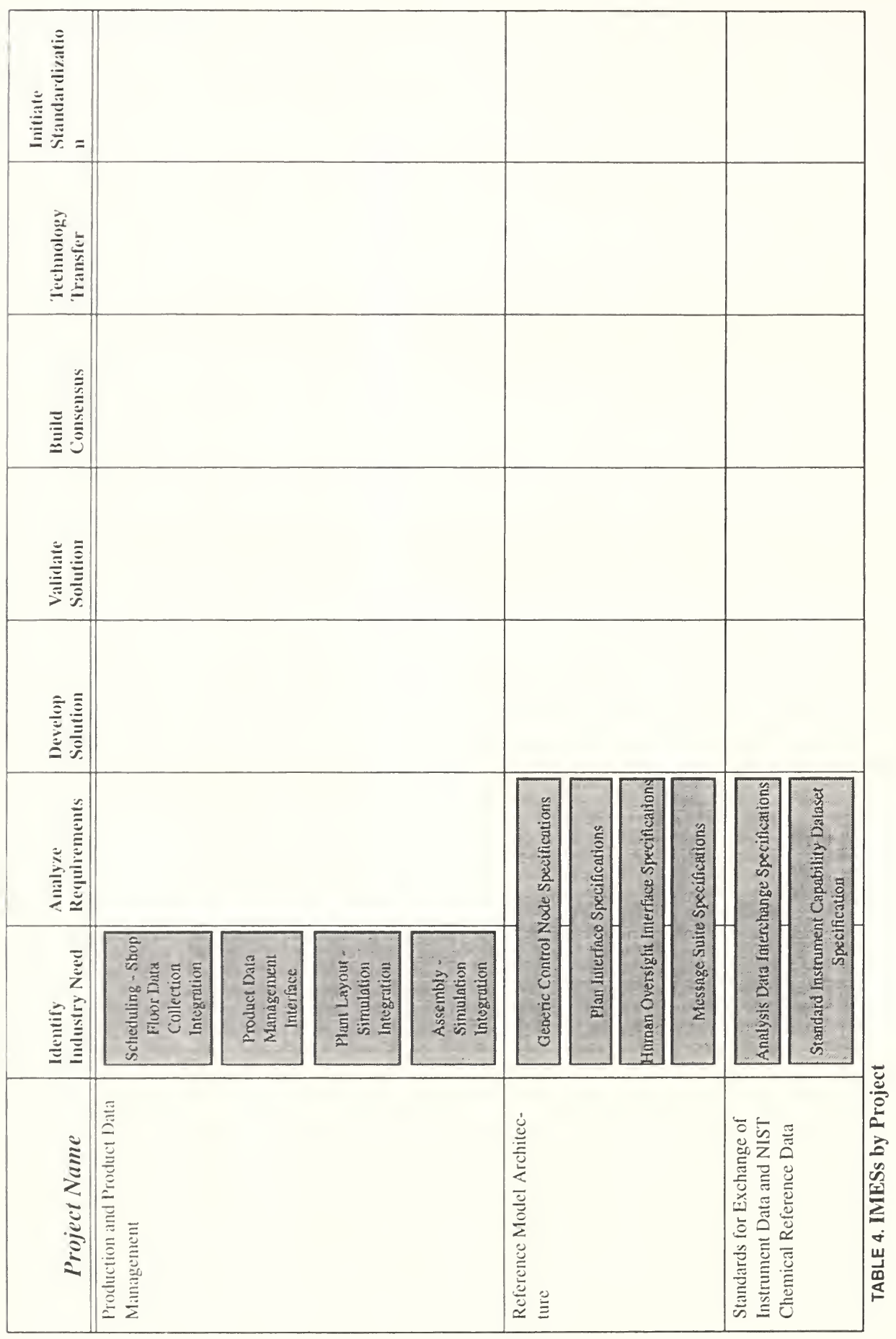


Information interfaces which are farthest advanced are those that have formally entered the standards development process. Specifications in these stages of development are typically those which have been in development for at least two years. Table 5 summarizes the seven international standards to which the projects have been contributing.

\begin{tabular}{|l|l|l|}
\hline \multicolumn{1}{|c|}{ Project Name } & Standard Designation & $\begin{array}{l}\text { FY96 } \\
\text { Status }\end{array}$ \\
\hline \hline $\begin{array}{l}\text { Electronic Commerce for the } \\
\text { Electronics Industry (ECCI) }\end{array}$ & $\begin{array}{l}\text { ISO 10303-210 Electronic Assembly, Interconnect, and } \\
\text { Packaging Design }\end{array}$ & $\begin{array}{l}\text { Commit- } \\
\text { tee Draft }\end{array}$ \\
\hline Framework & $\begin{array}{l}\text { ISO 10303-26 Interface Definition Language Binding to } \\
\text { the Standard Data Access Interface Specification }\end{array}$ & $\begin{array}{l}\text { Working } \\
\text { Draft }\end{array}$ \\
\hline $\begin{array}{l}\text { Process Planning Applications } \\
\text { ISO 10303-213 Numerical Control Process Plans for } \\
\text { Machined Parts }\end{array}$ & $\begin{array}{l}\text { Draft Inter- } \\
\text { national } \\
\text { Standard }\end{array}$ \\
\hline $\begin{array}{l}\text { Process Plant Engineering and } \\
\text { Construction }\end{array}$ & $\begin{array}{l}\text { ISO 10303-230 Building Structural Frame: Steelwork } \\
\text { Industries }\end{array}$ & $\begin{array}{l}\text { Commit- } \\
\text { tee Draft } \\
\text { for Com- } \\
\text { ment }\end{array}$ \\
\hline $\begin{array}{l}\text { STEP for the Process Plant } \\
\text { Virtual Environments and Visu- }\end{array}$ & ISO 10303-227 Plant Spatial Configuration & $\begin{array}{l}\text { Commit- } \\
\text { tee Draft }\end{array}$ \\
\hline
\end{tabular}

TABLE 5. Standards by Project

\section{Project Accomplishments}

The following descriptions provide summaries of each SIMA Program technical project. Project summaries are organized by program environment element (see Appendix A for a description of the organization of projects). Each project summary provides a brief description of objectives, accomplishments, and collaborations. Detailed information on any project may be obtained by contacting the project manager listed for that project. 


\section{Manufacturing Systems Environment Project Summaries \\ MSE1: Apparel Information Technology 1}

Project Manager: Howard Moncarz

Telephone: (301) $975-3548$

E-mail: moncarz@cme.nist.gov

This project has two main objectives. The first is to develop a formal specification of the enterprise model (including activity and information models) for the requirementsdetermination phase of the custom therapeutic footwear (CTF) manufacturing life cycle. The second objective is to develop a comprehensive data exchange specification for the design and manufacture of garments, combining best practices for both military and commercial requirements.

SIMA sponsorship for this project ended with FY96, due to the successful initiation of an industry-led effort for development of interoperability standards.

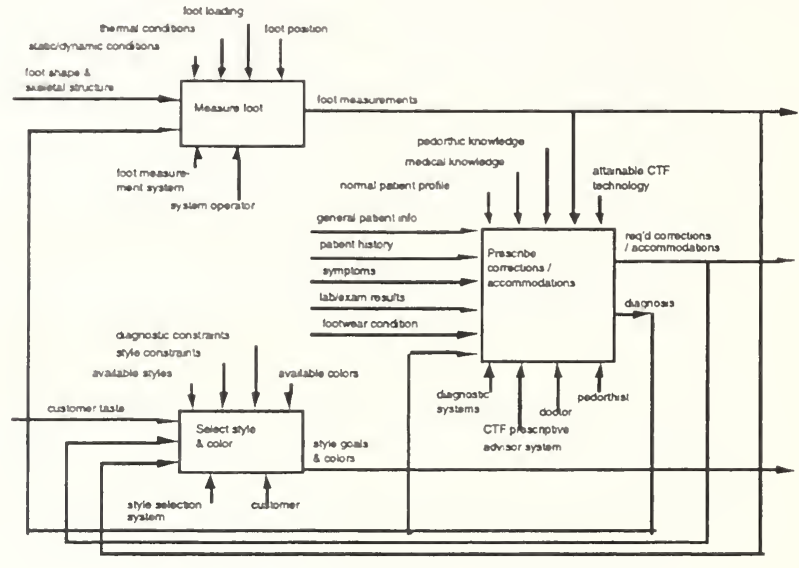

Activity model for requirements specification phase

\section{FY96 Accomplishments}

- Presented CTF project results at three footwear meetings: a "Round Table Meeting" of industry leaders in October, the annual Pedorthic Footwear Association Symposium in November, and the triennial SHOETECH Conference in December. As a result of NIST's efforts, the footwear industry established the Footwear Measurement Committee (FMC) to develop interoperability standards.

- Presented the preliminary activity model and information requirements of the CTF manufacturing enterprise to the FMC.

- Performed initial information requirements analysis of apparel product specification using garment specification sheets obtained from military suppliers, commercial manufacturers, and researchers.

\section{Collaborations}

- Defense Logistics Agency, to coordinate with the Apparel Research Network partners for identification of data requirements for a garment specification.

- Footwear Industries of America (FIA), to produce interoperability standards for the footwear industry.

- Pedorthic Footwear Association (PFA), to produce interoperability standards for the footwear industry.

1. Formerly known as the "Virtual Enterprise Frameworks for Small Manufacturers" project. 


\section{MSE2: Electronic Commerce for the Electronics Industry (ECCI)}

Project Manager: James St. Pierre

Telephone: (301) 975 - 4124

E-mail: jimstp@nist.gov

The objective of this project is to contribute to the technical development of the neutral product data exchange specifications and the component information infrastructure for the electronics industry. Towards this goal the project strives to resolve conflicts among competing and conflicting standardization efforts within the electronics industry. Project staff work with industry and other government laboratories to promote the transfer of technical information between the

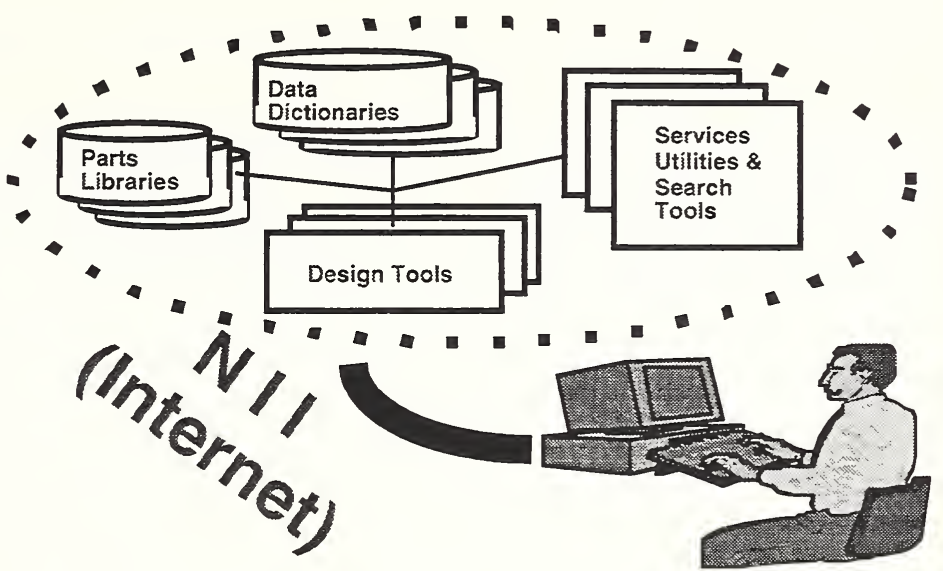

Engineering of electronic products via the internet

manufacturers of electronic parts and those who need parts for the design, manufacture, and repair of electronic systems. These efforts include research-based prototype development as well as IMES development.

Some of the technical areas addressed by this project are: the fundamental terminology used to describe components, the organization of the component data and metadata, and the ability to access this data and incorporate it into the lifecycle of a design. Assisting in the development of standards in this domain is crucial in order for U.S. electronics manufacturers to take advantage of the global marketplace. Industry and standards groups in both Japan and Europe are actively working on ECCI-related projects. This project will work with these groups to minimize overlapping standards development and to ensure interoperability between U.S. ECCI data and that of other countries.

Specific focus areas of the project include:

- interoperability between electronic product design tools,

- availability of on-line data dictionaries and common terminology in component descriptions,

- methods for coordinating product information creation, access and maintenance,

- integration of electronic product design tools via software frameworks,

- tools and methodologies for conformance and certification testing of software which use electrical product data exchange standards,

- methodologies for incorporating ECCI, and

- interoperability between existing standards. 
FY96 Accomplishments

- Continued leadership of IEC/TC93/W65 “Test Validation, Conformance and Qualification” standards committee.

- Developed prototype internet-accessible conformance testing architecture based on Java in conjunction with the Common Object Request Broker Architecture (CORBA).

- Developed prototype version of the IEC 1360 dictionary, including a graphical user interface for browsing of each software object/term as well as for submission of terms. Initiated development of a CD-ROM version of the dictionary.

- Developed prototype demonstrating a netlist connectivity model based on the project's specifications for an object-oriented printed circuit repository.

- Developed and submitted a geometric dimensioning and tolerancing data model for inclusion in ISO 10303-210 (Electronic Assembly, Interconnect, and Packaging Design).

- Reviewed version 3.9.9 of the EDIF (Electronic Design Interchange Format) standard and provided suggested changes to EIA (Electronic Industries Association).

- Acquired Viewlogic Digital Designer tools for purposes of investigating online component information and model services.

- Published draft specification for electronic product information viewer via internet. Initiated Small Business Innovative Research grant for development of software satisfying specification.

\section{Collaborations}

- CAD Framework Initiative, for development of online electronic component databooks standards.

- Electronic Industries Association, for resolution of issues on EDIF.

- IGES Data Analysis, for development of electronic product information viewer specifications.

- Naval Research Laboratory, for analysis of standards issues in the Microwave \& Millimeter-wave Advanced Computational Environment (MMACE) Program.

- PDES Inc., for development of ISO 10303-210.

- SEMATECH, for validation of the CIM Framework.

- Viewlogic Systems Inc., for analysis of electronic component data requirements in electronic engineering and design software. 


\section{MSE3: Information Protocols for Design 2}

Project Manager: Ram Sriram

Telephone: (301) 975 - 3507

E-mail: ram.sriram@nist.gov

This project working to develop appropriate standards and protocols for interoperability of design with other engineering tasks, such as process planning and production engineering. Specific objectives of the project are as follows:

- to enhance ISO 10303 ("Standard for the Exchange of Product Model data") for the capture and exchange of parametric, constraint-based and feature-based models such as are generated by all major modern computer-aided design (CAD) systems,

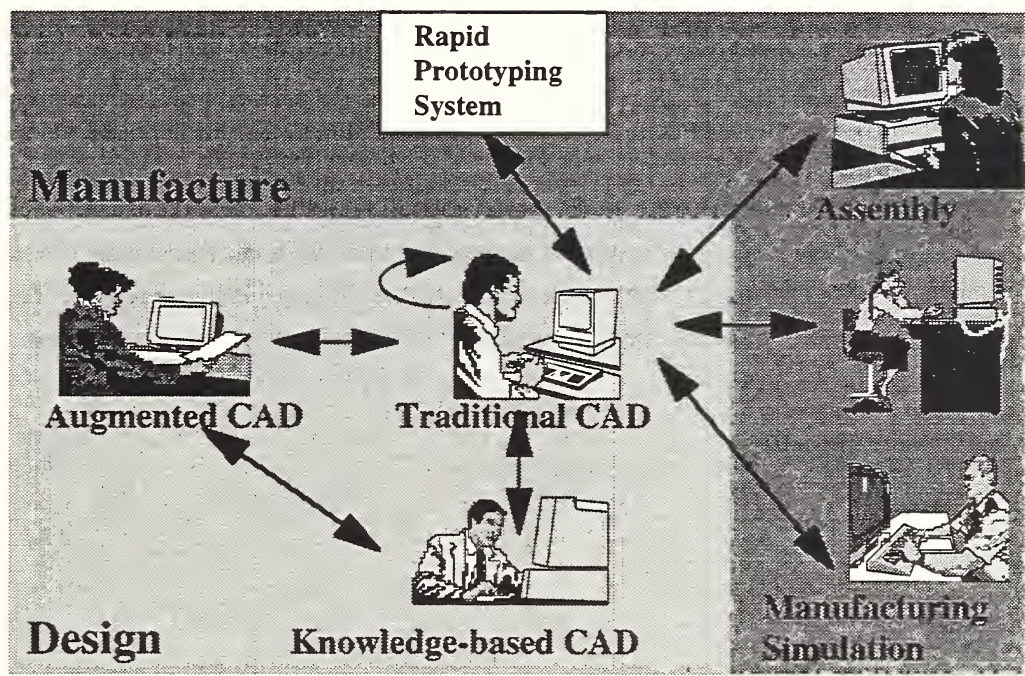

Interactions between design process and manufacturing

- to assess the applicability of ISO 10303-224 (Mechanical product definition for process plans using machining features) to specific manufacturing systems integration problems, to identify improvements, and to assist in its standardization,

- to develop an IMES for the exchange of design data between CAD systems and rapid prototyping systems,

- to address integration issues of linking assembly oriented tools (e.g., virtual assembly and design-for-assembly) to traditional CAD systems, and

- to explore the development of engineering ontologies for communication of design knowledge information.

\section{FY96 Accomplishments}

- Chaired meetings of the ISO TC184/SC4 Parametrics group working towards parametric representations.

- Presented parametrics-related work at American Society of Mechanical Engineers (ASME) Computers in Engineering conference and Computer-aided Design Exchange (CADEX) conference. Organized an International Federation for Information Processing (IFIP) workshop on Geometric Modeling for CAD Applications.

- Developed a requirements analysis for explicit geometric constraints and submitted it to the appropriate STEP working groups.

- Demonstrated exchange of $\mathrm{CAD}$ data between prototype knowledge-based design for assembly systems, a commercial CAD system, and a Virtual Reality Modeling Language environment.

- Demonstrated the Virtual Assembly Design Environment (VADE) with an interface to a commercial CAD system, showing how kinematic constraints can be incorporated into CAD systems.

2. Formerly known as the "Design Applications" project. 


\section{Collaborations}

- Boeing, for cooperative work in design and analysis issues and integrated product and process modeling.

- Caterpillar, for investigation of $\mathrm{CAD}$ and virtual reality integration issues.

- Defense Advanced Research Projects Agency Enabling Next Generation Design (ENGEN) project, for development of parametric and constraint representation specifications.

- D.H. Brown Associates' Open CAD Architecture Interface project, for development of feature-based representation specifications.

- Isothermal Systems Research, Inc., for development of integration mechanisms to enable virtual prototyping of mechanical components.

- Purdue University, for investigation of issues related to physics-based modeling.

- Stanford University, for investigation of engineering ontologies and knowledge interchange representations.

- University of Maryland, for investigation of integration between knowledge-based design and traditional CAD.

- Washington State University, for investigation of $\mathrm{CAD}$ and virtual reality integration issues. 


\section{MSE4: Framework ${ }^{3}$}

Project Manager: Neil Christopher

Telephone: (301) 975 - 3888

E-mail: neil.christopher@nist.gov

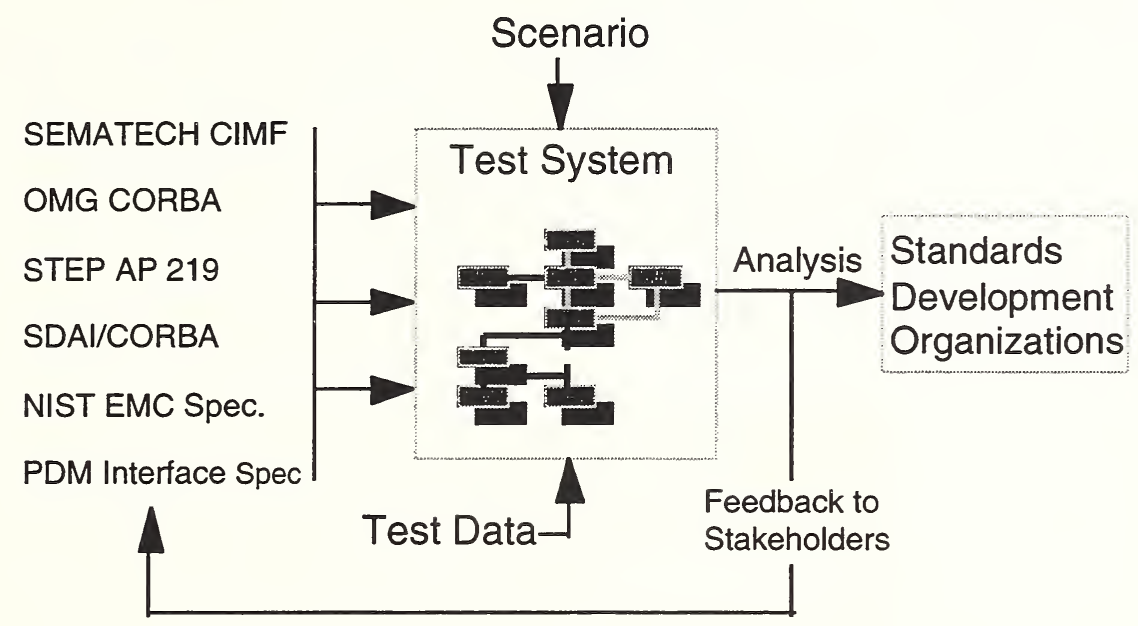

Framework Test System

The objective of this project is to validate a framework of pre-standard software services that enable the integration of distributed manufacturing software applications. This project works with industry consortia to characterize classes of manufacturing applications software, describe interfaces to those classes of software, and model information used by those classes of software. The services, interface descriptions, application characterizations, and models will be published as specifications for the integration of distributed manufacturing software applications. These specifications constitute a "framework" for the integration of distributed manufacturing software systems. These framework specifications are being validated through the creation of a working prototype and the validated framework elements will be promoted through standards organizations. It is expected that, through close collaboration with industry, these specifications and standards will enable the creation of software products that will assist in reducing the manufacturing cycle time of mechanical component production.

3. Formerly referred to as the "Integration Mechanisms" project. 


\section{FY96 Accomplishments}

- Completed the initial analysis and review of the SEMATECH Computer Integrated Manufacturing Applications Framework version 1.3 (CIM-F). Provided recommendations to SEMATECH as a result of the analysis. Completed development of an information model of the SEMATECH CIM-F specification.

- Completed specifications for a prototype system that includes the following components: shop controller, production information base, product data manager, guardian user interface, workcell controller hierarchy, coordinate measuring machine, simulation system, and operator work instruction module. Completed system component interface definitions, software implementations, and software integration.

- Completed the design and implementation of a Standard Data Access Interface (ISO 10303-22) using the CIM-F information models on a commercial object-oriented database.

- Completed contributions to the Object Management Group's (OMG) Manufacturing Domain Task Force Whitepaper, Product Data Management Interface Request For Proposal, and initiated contributions to the OMG Real-time Special Interest Group.

- Conducted two industry workshops, one of which was to review the work planned by the project and the other to determine the scope of an information model for inspection operations.

Collaborations

- NIIIP (National Industrial Information Infrastructure Protocols), for analysis of manufacturing integration architectural approaches.

- SEMATECH, for investigation of integration methodologies and frameworks.

- Software Engineering Institute, for validation of CORBA-based software implementation.

- Technologies Enabling Agile Manufacturing (TEAM), for analysis of integration solutions. 


\section{MSE5: Operator Interfaces for Virtual and Distributed Manufacturing}

Project Manager: Ernie Kent

Telephone: (301) 975 - 3460

E-mail: ernest.kent@nist.gov

The objective of this project is to understand and address standards issues in human interfaces for virtual and distributed manufacturing systems. The project is developing methods to collect and present relevant manufacturing information at an appropriate level of abstraction for interactively examining remote operations, and cooperatively controlling remote systems.

The focus is not only on remote interaction with shopfloor equipment, but also on interfaces for development, management and control of plant, operations, processes, and design at a variety of levels such as shop-floor supervisor, production foreman, plant manager, production executives, facility designers, product designers, process designers, and consultants. The general problem is to collect and present the relevant information, at the appropriate level of detail, and in the most efficient possible format, to a variety of remote decision-makers and allow them to examine interactively remote situations and cooperatively control the remote environments. Issues with which the project is concerned are:

- the definition of the information needs of end-users

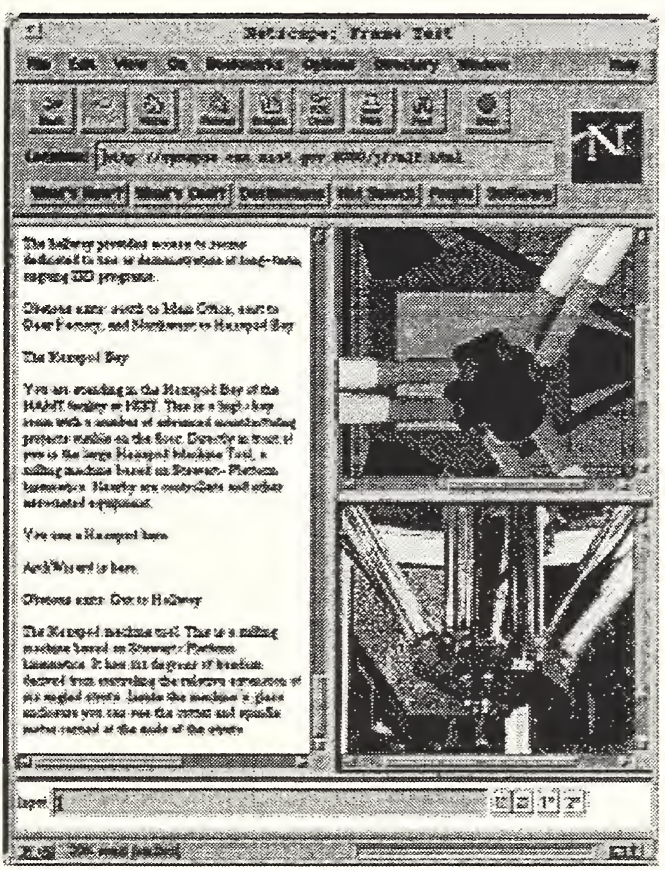

Prototype Web Interface for Hexapod Machine Tool that must flow across the interface between manufacturing databases and display systems appropriate for presenting the information to human operators,

- the development of standard interfaces between operating manufacturing databases and user-display systems appropriate for presentation to human operators,

- the exploration of advanced technologies for presenting the information in real-time to enable identification of interface standards issues. Two current technologies being investigated are graphics-based virtual reality techniques oriented towards real-time, single user displays, and text-based multi-user shared environments.

\section{FY96 Accomplishments}

- Developed prototype interface between Immersadesk and NIST's octahedral hexapod machine tool simulations.

- Demonstrated use of Immersadesk for display of 3-dimensional models of range images with each pixel being represented by a tile whose color indicates its range.

- Developed prototype capabilities for interfacing multiple, simultaneous, remote users to one another, to local operators, and to controlled systems using coordinated graphics and bidirectional text-based interactions over the Internet.

\section{Collaborations}

- University of Illinois, to enhance Immersadesk capabilities.

- Deneb Robotics, for technology transfer of Immersadesk interface software into their products. 


\section{MSE6: Process Planning Applications}

Project Manager: Shaw Feng

Telephone: (301) $975-3551$

E-mail: shaw.feng@nist.gov

The objective of this project is to identify, develop, deploy and promote several infrastructural standards needed for integration of manufacturing process planning. The project is focusing its efforts on three specifications:

- Process planning for Numerical Controlled (NC) machining (ISO 10303-213) which specifies the information to be exchanged between process planning applications and NC programming applications,

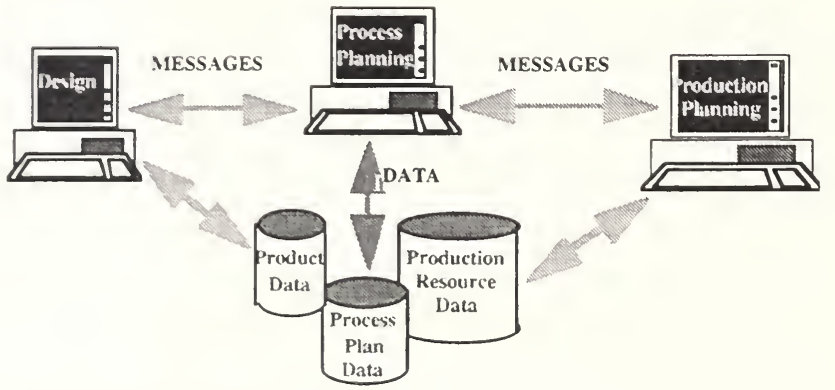

Interactions between engineering design and process planning systems

- Process planning Application

Programming Interface (API) which is intending to specify a generic programming interface to process planning software, and

- Process specification language, an exchange specification generally applicable across a range of application domains.

\section{FY96 Accomplishments}

- Defined and documented process planning activity model.

- Analyzed two commercial process planning systems with respect to their process plan representations, as a precursor to pilot standards implementations.

- Created repository of sample product and process data for testing of engineering applications.

- Completed and documented a preliminary modular, composable process planning architecture.

- Initiated a collaborative effort with IAMS (Institute for Advanced Manufacturing Sciences) to build a pilot implementation of ISO 10303-213 using their MetCAPP process planning system.

- Collected, analyzed, and categorized functional and representational requirements for process representation through research of multiple manufacturing application areas.

- Established process specification language web pages to enable collaboration through improved communication and to promote outreach and consensus through technology transfer and feedback mechanisms (http:// www.nist.gov/psl).

- Coordinated the collection and compilation of U.S. ballot comments for ISO 10303-213 to generate a U.S. position on its promotion to Final Draft International Standard.

- Created a demonstration showing process plan generation using MetCAPP, creation of a ISO10303-213 file for the process plan, check-in/check-out of the plan via a product data management application, and NC tool path generation using SmartCAM. The exchanged process plan contained machining process plan information including operations, sequence of operations, tool selections, and machining parameters (feeds, speeds, depths of cut).

- Presented the paper "Open Systems Interface Specification for Machining Process Planning Integration" at the 12th International Conference on CAD/CAM Robotics and Factories of the Future. 


\section{Collaborations}

- CAMAX, for validation NC programming application information requirements using their NC programming system, SmartCAM.

- $\mathrm{CIMx}$, for validation of process planning application information requirements using their process planning system, CS/CAPP.

- CNC Software, Inc., for validation of NC programming application information requirements using their systems, Mastercam.

- George Washington University, for investigation of requirements for process specification languages.

- Institute for Advanced Manufacturing Sciences (IAMS), for work on a pilot implementation of ISO 10303-213.

- PDES Inc., for coordination of the ballot process on ISO 10303-213 and to participate in abstract test suite development.

- Technologies Enabling Agile Manufacturing (TEAM), for definition of requirements for integrated process planning.

- University of Maryland, for investigation of requirements for process specification languages. 


\section{MSE7: Process Plant Engineering and Construction}

Project Manager: Kent Reed Telephone: (301) 975 - 5852

E-mail: kent.reed@nist.gov

The objective of this project is to work with U.S. industry to develop a technical capability to represent and exchange information supporting the design and construction of structural systems using internationally accepted protocols.

The U.S. construction industry seeks to improve its use of computerized systems through integration, e.g., automation of the exchange and sharing of information among systems. The evolving international standard ISO 10303 ("STEP") is providing the base technology. The U.S. structural engineering community has recognized the advantages of STEP and seeks to make STEP exchange viable in its computerized design, analysis, and fabrication systems.

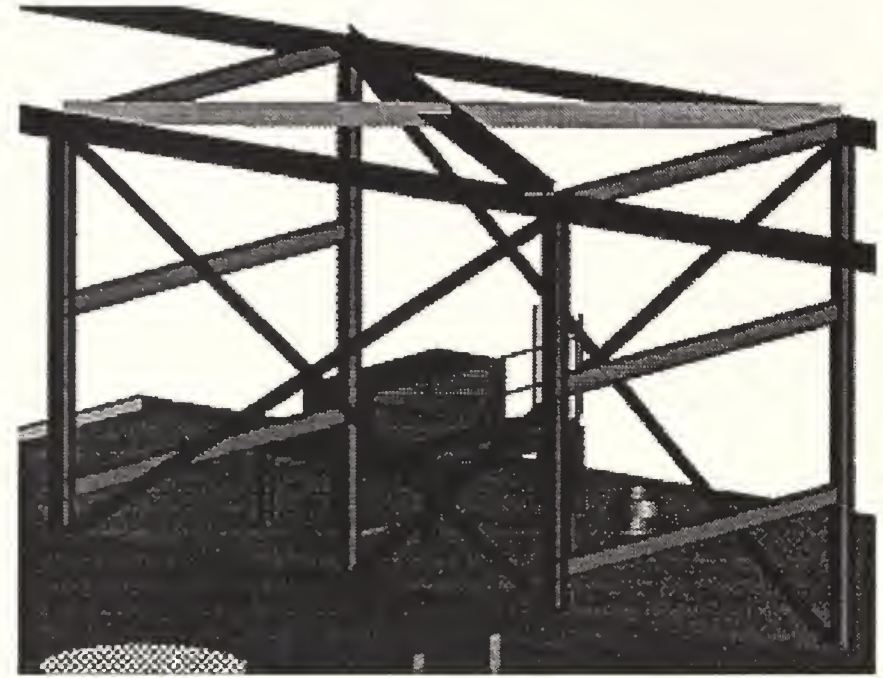

Structural steel frame model

The ISO committee responsible for STEP has undertaken a New Work Item (NWI) to develop STEP Application Protocol 230, "Building Structural Frame: Steelwork." Technical results of the European CIMSteel program have been submitted as the basis for this project. In response to the NWI, the American Institute of Steel Construction (AISC) has established a Software Committee to participate in the development of this standard. This SIMA project is working with the AISC committee to ensure it understands the underlying STEP technology and to ensure the U.S. industry's technical requirements are met in the resulting standard.

\section{FY96 Accomplishments}

- Established new research relationship with University of Maryland for technical work on assessment of ISO 10303-230.

- Acquired and installed a number of commercial software packages for use in analysis of U.S. industry requirements in comparison to ISO 10303-230 and initiated development of test designs.

\section{Collaborations}

- American Institute of Steel Construction, for participation in the data exchange task group and serving as its government liaison member.

- Carnegie Mellon University, for analysis of the proposed ISO 10303-230 in the context of U.S. industry requirements.

- University of Maryland, for analysis of the proposed ISO 10303-230 in the context of U.S. industry requirements. 


\section{MSE8: Production and Product Data Management ${ }^{4}$}

Project Manager: Charles McLean

Telephone: (301) 975 - 3511

E-mail: charles.mclean@nist.gov

This project is addressing integration problems associated with product data management, production engineering, scheduling, and simulation systems. The project is developing process models, information models, and interface specifications, databases, and extensions to commercial production software that resolve or facilitate system integration. After assessing industry needs, this project has selected and installed software applications that are used to engineer a production system, perform production scheduling, and simulate production. Prototype integrated systems are being constructed from commercial products and industry provided data. The principal elements of the technical approach are to:

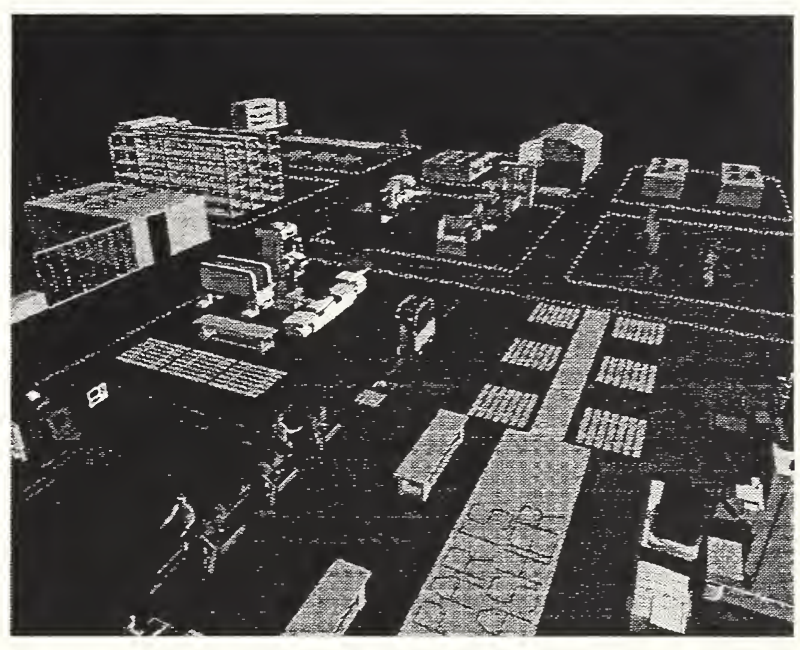

Simulated production facility

- identify and address critical industrial needs through collaboration,

- develop solutions to production software integration problems,

- construct prototype solutions using commercial products,

- validate results through industrial testing of system implementations, and

- specify and promote needed industry standards, and facilitate rapid commercialization of new technology.

4. Formerly known as the "Production Applications" project. 


\section{FY96 Accomplishments}

- Developed an information model for shop floor status data, created database schema from the information model, populated that database with test data, and ran queries against that data.

- Developed system architecture for the scheduling system, defined initial exchange protocols for the transfer of shop floor status from data collection system to scheduling system, specified structure and syntax of the messages which are generated by the shop floor simulator and used to update the status database.

- Worked with scheduling system vendors to demonstrate integration of scheduling and shop floor data collection using a simulated casting facility, status database, and the vendor's scheduling systems.

- Reviewed several sources of product data management interface requirements including: ISO 10303-203, Application Protocol: Configuration-controlled design (AP203), Rapid Response Manufacturing consortium's "Interoperable Product Structure Services Provider", and SEMATECH CIM Framework Specification.

- Constructed an initial specification for a product data management interface, supporting document management, including check-in and check-out, and part configuration management.

- Implemented and tested the product data management interface using a commercially available product data management system through a Common Object Request Broker Architecture interface.

- Developed an initial information model for manufacturing plant layout data based on entities found in ISO 10303 227, ISO 10303-203 and the ISO 1030340 series Integrated Resource (IR) parts.

- Demonstrated implementation of the manufacturing plant layout information model via integration of a factory layout application with a manufacturing simulation system. 


\section{Collaborations}

- Adra Systems Inc., for integration of product data management with manufacturing applications.

- AMP, Inc., to provide test data and for use of integrated scheduling and shop floor data collection.

- AutoSimulation, Inc., for developing and demonstrating integration of scheduling and shop floor data collection.

- Black and Decker, to provide test parts and manufacturing data.

- Boeing, to provide test data and for validation of manufacturing data packages.

- Brigham Young University, for development of interfaces between process specification and simulation.

- California Polytechnic University, for integration of project management and budgeting applications with production system engineering applications.

- CIM Technologies, for integration of plant layout software with simulation software.

- Deneb Robotics, for investigation of issues related to simulation system interfaces.

- DLOG Corp., for demonstrating integration of scheduling and shop floor data collection.

- Framework Technologies, for integration of manufacturing system applications and data.

- McDonnell-Douglas, to provide test parts and manufacturing data.

- Michigan Technological University, for development of interfaces between assembly process specification and simulation.

- Northeastern University, for investigation of use manufacturing engineering software to disassembly of products.

- Ohio University, for engineering tool integration, simulation, and other system interfaces.

- Pritsker Corporation, for developing and demonstrating integration of scheduling and shop floor data collection.

- ProModel Corp., for development of interfaces between process specification and simulation.

- Purdue University, for demonstrating integration of scheduling, shop floor data collection, and simulation.

- Rapid Response Manufacturing (RRM) consortium, for definition of product data management and manufacturing application interfaces.

- SEMATECH, for definition of product data management and manufacturing application interfaces.

- Technologies Enabling Agile Manufacturing (TEAM) consortium, for definition of product data management and manufacturing application interfaces.

- University of Maryland, for integration of plant layout and simulation.

- Virginia Polytechnic Institute, for development of interfaces between process specification and simulation.

- Wonderware Inc., for demonstrating integration of scheduling and shop floor data collection. 


\section{MSE9: Reference Model Architecture}

Project Manager: Harry Scott

Telephone: (301) 975 - 3437

E-mail: harry.scott@nist.gov

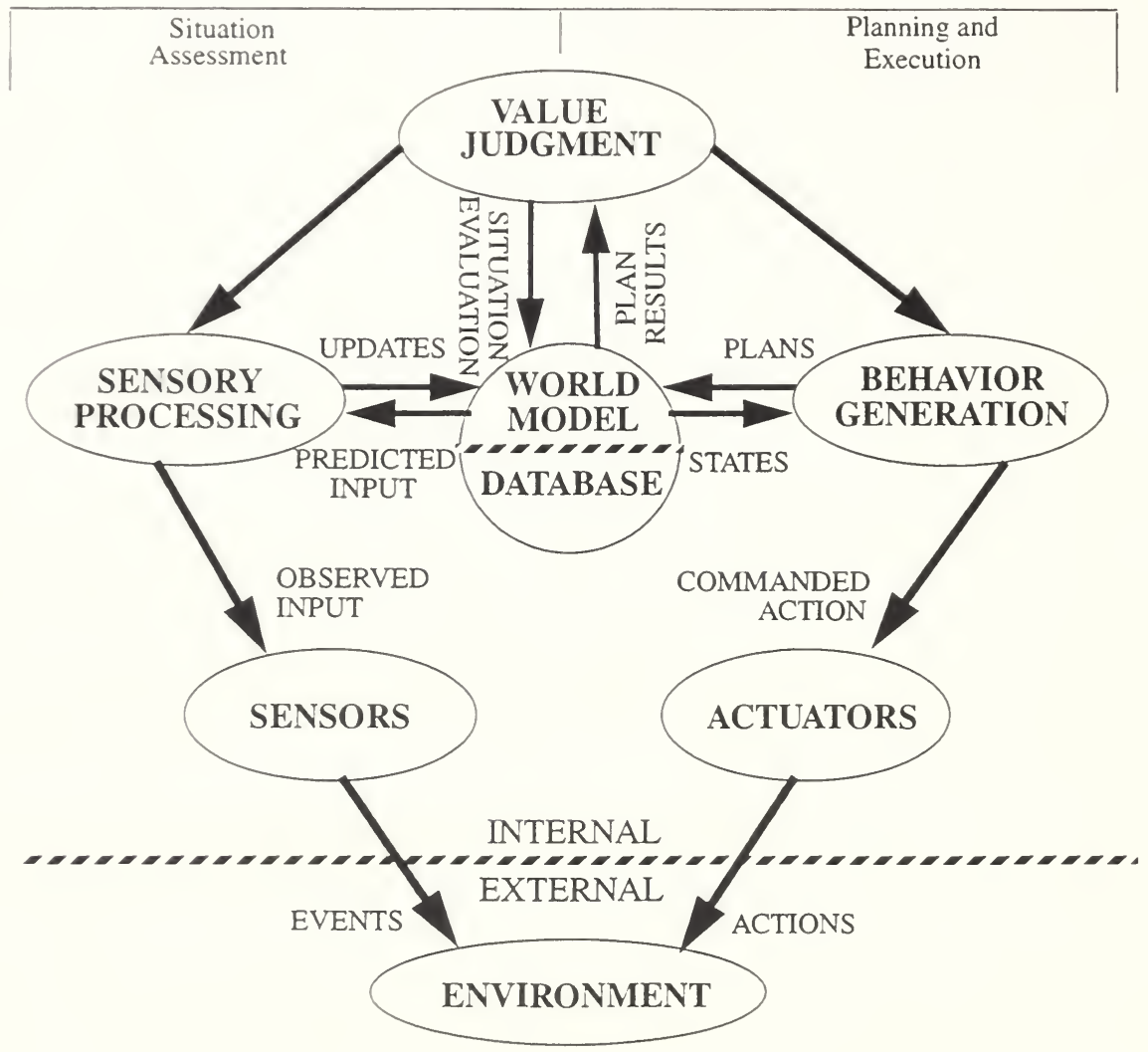

Abstract model of the architecture

The objective of this project is to develop a detailed design of a reference model architecture for intelligent control of manufacturing processes and to demonstrate, validate and evaluate the NIST Reference Model Architecture through analysis and performance measurements of a simulated and prototype implementation. The approach includes leveraging the work of other programs, such as the NIST Enhanced Machine Controller, in developing interface specifications among the architectural components, and working with industry in developing tools to support development of Reference Model Architecture-based system implementations. The goals of this work are to provide U.S. industry with state-of-the-art manufacturing architectures and models, foster the development and implementation of advanced manufacturing systems, and anticipate and address the needs of the U.S. manufacturing industry for the next generation of advanced systems and standards. 


\section{FY96 Accomplishments}

- Completed requirements analysis for definition of generic control module shell.

- Implemented and demonstrated initial version of the inspection workstation testbed. The control system for the inspection workstation included control nodes developed from $\mathrm{C}++$ control module templates and are the baseline control modules for further Reference Model Architecture generic module development. The demonstration included shop-level control concepts along with those at the workstation, task, and lower levels, and provided the much needed testing capabilities for further resolution of relevant architecture issues in developing a single Reference Model Architecture node definition.

- Developed a Dimensional Measuring Inspection Specification (DMIS) inspection plan interpreter, providing insights into requirements of the control system in the use of legacy standards (where available) for plans and providing a key component of the inspection testbed.

\section{Collaborations}

- Advanced Technology and Research, Co., for development of real-time control system software and supporting tools.

- Catholic University, for development of inspection-related software.

- Drexel University, for development of experimental planners and schedulers.

- National Center for Manufacturing Sciences (NCMS), for development of the NGIS control system.

- Technologies Enabling Agile Manufacturing (TEAM) Consortium, for development of message interfaces as part of the Intelligent Closed Loop Processing effort and for development of an enhanced machine controller (EMC). 


\section{MSE10: STEP for the Process Plant Industries}

Project Manager: Mark Palmer

Telephone: (301) 975 - 5858

E-mail: mark.palmer@nist.gov

This project is working with industry to develop, test and demonstrate the STEP application protocols needed for exchanging and sharing information during the design, construction, operations, and maintenance of process plants.

The objectives of this project are:

- analyze the information exchange problems and needs of the process plant industries,

- define a strategy for the collaborative development of the STEP application

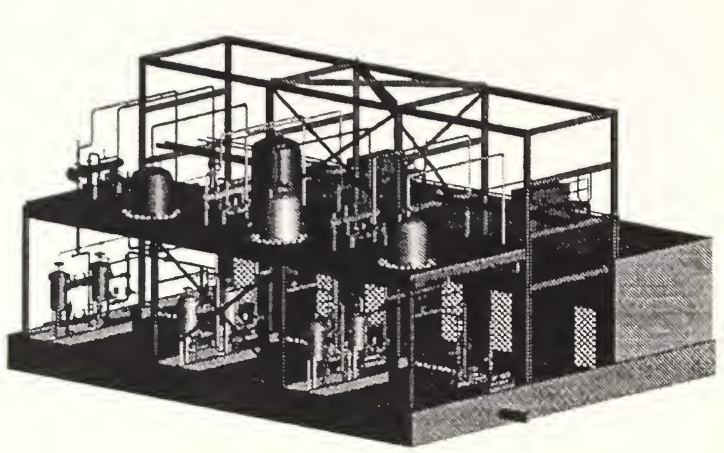

Process plant model protocols (APs) that meet the industries' requirements,

- work with industry to develop and validate the highest priority APs, and

- demonstrate prototypes and support the industrial implementation of these APs as international standards.

FY96 Accomplishments

- With PlantSTEP, Inc., completed the Plant Spatial Configuration Application Protocol (ISO 10303-227), Version 1.0 and distributed to ISO TC184/SC4 for committee draft ballot.

- With PlantSTEP, Inc., conducted an industry seminar on STEP for the Process Industry in 1996 and Beyond. Held in conjunction with international Plant Design/ Plant Automation Conference.

- With pdXi, completed and distributed for limited, industry review the initial application reference model and requirements document for the Process Engineering Data Application Protocol (ISO 10303-231).

- Completed the "Scope and Requirements for Process Engineering Data Application Protocol" and distributed it for international industry review.

- Completed the ISO committee draft ballot review of ISO 10303-227 resulting in its promotion to draft international standard (DIS) ballot.

\section{Collaborations}

- International Society of Measurement and Control (ISA), on the ISA STEP Committee to develop the ISA STEP implementation plan.

- PIEBASE (Process Industry Executive for achieving Business Advantage using Standards for data Exchange), to establish an international coordination council.

- PlantSTEP, Inc., for development and testing of draft data exchange standards and interoperability testing of trial implementations.

- Process Data eXchange Institute of AIChE (pdXi), for development and testing of draft standards for exchanging process engineering data. 


\section{MSE11: Virtual Environments and Visualization for Manufacturing 5}

Project Manager: Sandy Ressler

Telephone: (301) 975 - 3549

E-mail: sressler@nist.gov

The objective of this project is to create new visualization environments which assist the manufacturing industry in achieving systems integration of manufacturing applications. Our approach is to enhance manufacturing applications with several kinds of Virtual Environment (VE) technology. Current limitations of both immersive and non-immersive VE technology are being examined. In addition VE standards which will enhance the manufacturing process are being investigated. In addition to "traditional" VE using a computer-generated polygonal environment, image-based VE is being explored. The combination of a polygonal and image-based environments may prove to be

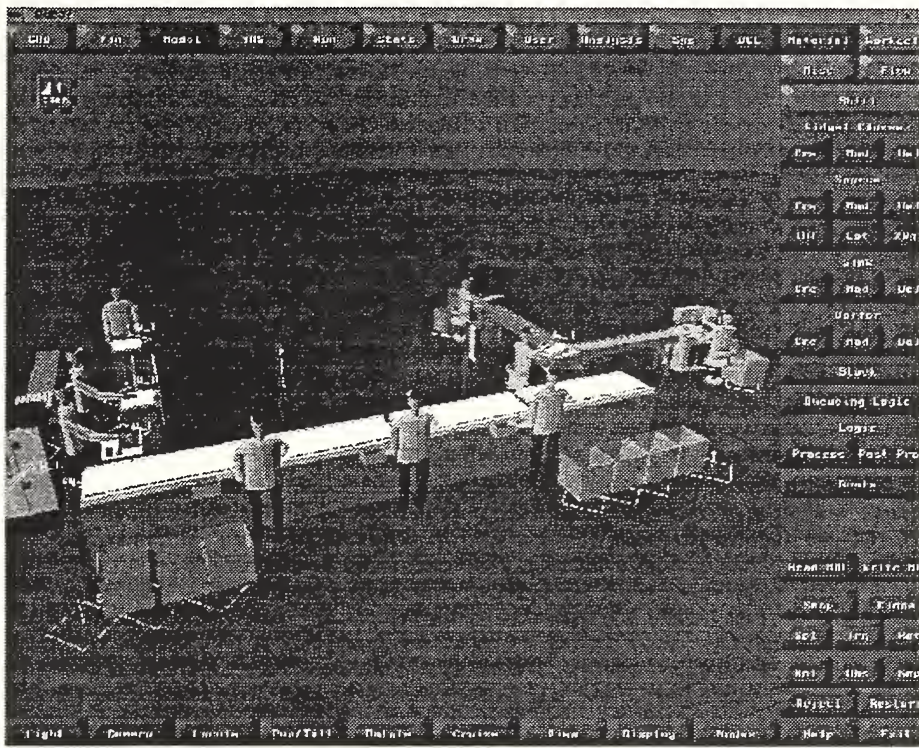

Simulation model of product assembly line highly usable as a method to interact with a virtual factory.

\section{FY96 Accomplishments}

- Demonstrated the use of an image-based texture in a polygon-based environment showing the initial work on "fusion" of the two techniques.

- Developed a fully immersive environment for a fan press from the Black \& Decker factory floor. The environment uses head mounted display, a cyberglove, and position tracking. Demonstrated initial work on use of cyberglove with gesture editing and recognition.

- Developed software for transforming simulation models in Deneb Robotic's Quest application into VRML representations. Converted existing Black \& Decker factory floor simulations into VRML. Made the conversion software available on the project's web page.

- Maintained an active web site providing information on the project's efforts. Web site includes factory floor VRML models, VRML conversion software, and VRML manipulation filters.

- Developed and demonstrated "Visual Interface to Manufacturing," a multimedia system employing multiple interaction technologies to provide a prototypical user with manufacturing process instructions.

\section{Collaborations}

- Black and Decker, for provision of test parts and sample manufacturing data.

5. Formerly known as the "Virtual Reality for Manufacturing" project. 


\section{Standards Development Environment Project Summaries}

\section{SDE1: Application Protocol Development Environment (APDE)}

Project Manager: Lisa Phillips

Telephone: (301) 975 - 5021

E-mail: lisa.phillips@nist.gov

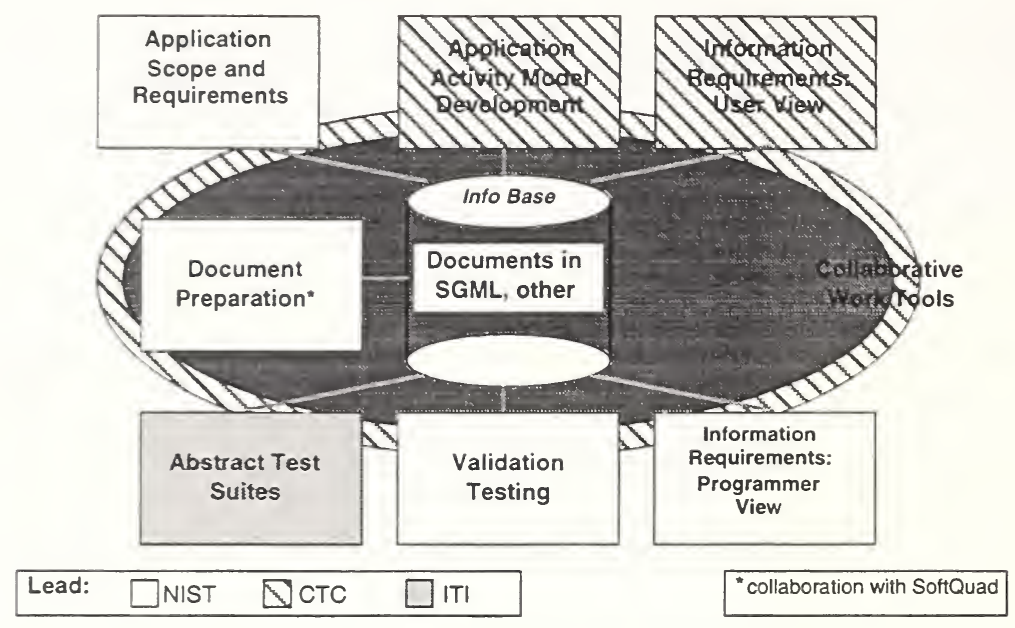

APDE components

The APDE project is accelerating the development of ISO 10303 ("STEP") and aiding application protocol (AP) developers in creating STEP specifications more efficiently, with high quality and at a lower cost, by establishing an integrated suite of software tools. Application protocols submitted to ISO must meet specified criteria for standardization and usually require extensive rework before they are allowed to progress through the standards process. Current practices used for AP development require extraordinary labor expenditures on behalf of AP developers to define AP documents. While AP developers may use some software tools to help them accomplish their AP development tasks, the tools work independently, are not integrated, and have not been customized specifically for the purpose of AP development.

The software tools being developed in the APDE project are integrated and they interact with a central information repository at NIST. The repository consists of STEP-related documents and data, much of it represented in Standard Generalized Markup Language (SGML). As the project matures, collaboration with various software suppliers will be established. The APDE goal is $40 \%$ reduction of the AP development cycle time, currently estimated at 2-4 years with 4-6 full time equivalent staff. 


\section{FY96 Accomplishments}

- Integrated commercial text database to enable faster queries and easier data access to SGML-tagged STEP documents.

- Designed and implemented web interface to STEP document repository.

- Built a web-accessible database application for maintaining a registry of short names corresponding to entity names in the ISO TC184/SC4 standards.

- Built SGML publishing application for documents developed using SGML document type definitions (DTDs) for STEP.

- Obtained approval from ISO TC184/SC4 to accept documents produced using STEP DTDs as a means of accelerating the publication process.

- Updated STEP DTDs to make use of public identifiers and other SGML features, enabling easier reuse and increased portability of DTDs.

- Provided technical support for STEP application protocol teams to ensure that software works as intended and that metrics are achieved.

\section{Collaborations}

- Bernier and Associates, for development of tools to gather and analyze information requirements addressed within an AP.

- Concurrent Technologies Corporation, for joint development of AP development tools and methods.

- DiK, for provision of SGML requirements for APs.

- Industrial Technology Institute, for development of tools to be used within the APDE.

- SoftQuad, Inc., for customization of SGML editing tools for the STEP community.

- STEP Tools, Inc., for use of their software tools in the development of the APDE. 


\section{SDE2: Protocol Testing for Process Plant Representations ${ }^{6}$}

Project Manager: Kent Reed

Telephone: (301) 975 - 5852

E-mail: kent.reed@ nist.gov

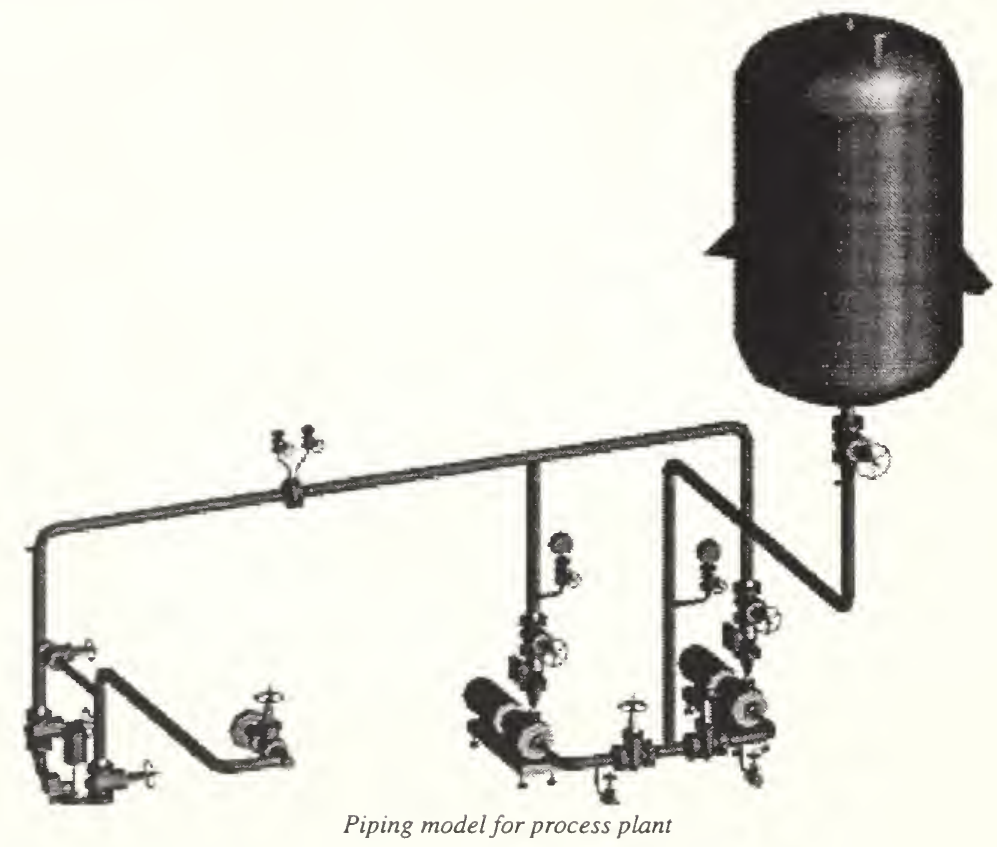

The objective of this project is to establish an experimental computing and communication facility to:

- provide a baseline of industrial practice in process plant engineering and construction,

- support the companion projects -- "STEP for the Process Plant Industries" and "Process Plant Engineering and Construction,"

- serve as an open testbed for integration activities of industrial partners, and

- serve as a communications hub for all U.S. participants.

\section{FY96 Accomplishments}

- Developed and publicly demonstrated the capability of the draft ISO10303-227 application protocol, Plant Spatial Configuration, in concert with four vendor/implementor members of the PlantSTEP, Inc., consortium. The project created and validated five test-case data sets for use by the participants in understanding the application protocol and developing their translator software.

- Implemented a schema for 10303-227 in a relational database. Structured Query Language (SQL) scripts were developed to generate reports on the process plant items transferred into the database from implementor's exchange files.

\section{Collaborations}

- PlantSTEP, Inc., for development and testing of draft data exchange standards and interoperability testing of trial implementations.

6. Formerly known as the "AMSANT for Process Plant Industries" project. 


\section{SDE3: STEP Conformance Testing}

Project Manager: Mary Mitchell

Telephone: (301) 975 - 3287

E-mail: mitchell@cme.nist.gov

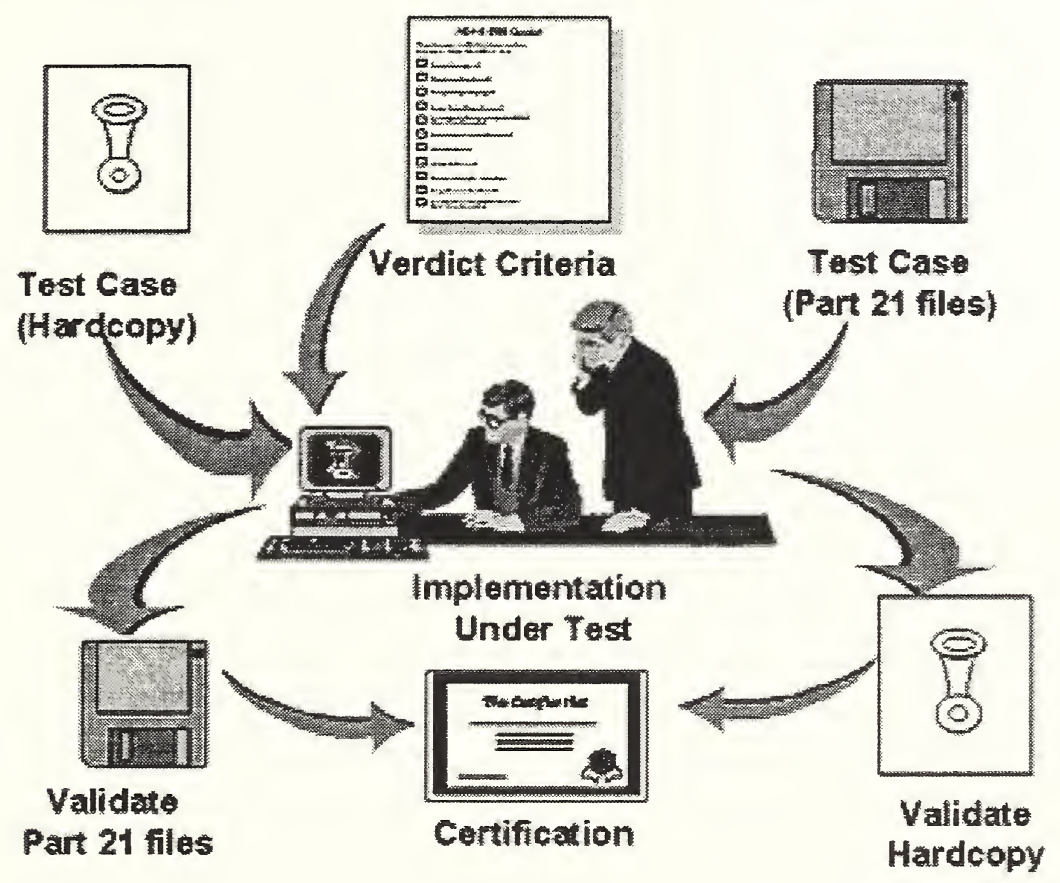

Conformance testing process

This project is providing the means by which vendor's software products will be measured for conformance to the ISO 10303 ("STEP") standard, through development of a set of value added software tools that will be made available for vendors to use during their product development process. Under this approach, vendors gain confidence that their products can successfully pass testing, vendors have access to tools that improve the quality of their products and reduce the costs of software testing, and vendors gain in the expanded market that user confidence in testing brings.

\section{FY96 Accomplishments}

- Developed guidelines for creation of STEP test suites. Guidelines received international review through ISO and were approved as a standing document.

- Implemented enhancements to the STEP Testing Harness including a browser/editor for schemas and exchange files and a test coverage analyzer.

- Implemented capability enhancements, procedural improvements, and additional test coverage for the webaccessible STEP conformance testing system based on feedback from its use in numerous industry pilot efforts (e.g., PowerSTEP and AutoSTEP)

- Developed initial test suite for ISO 10303-302 (Associative Drafting). This effort helped identify and resolve issues related to the development of the test suites required for all STEP application protocols.

- Developed and submitted new work item to ISO for test methods for implementations of ISO 10303 -22 (Standard Data Access Interface). 


\section{Collaborations}

- Boeing, for evaluation of conformance testing services and for investigation of geometric representation analysis techniques and software.

- Ford Motor Company, for contributions to the design of geometric comparison algorithms and on issues of solid model quality.

- Industrial Technology Institute, for development of STEP test systems and test methods.

- PDES Inc., for validation of conformance testing system through pilot implementation projects. 


\section{SDE4: STEP Implementation Prototypes ${ }^{7}$}

Project Manager: Simon Frechette

Telephone: (301) 975 - 3335

E-mail: simon.frechette@nist.gov

This project is accelerating the adoption of ISO 10303 ("STEP") by promoting development of industry consensus on implementation and facilitating implementation of production-ready STEP applications. NIST is working with industry to identify requirements for interoperable systems by providing guidance on implementing STEP, by developing test methodologies and data exchange metrics, and by testing STEP translators within the context of industrial pilots. NIST is working to ensure implementation experience is fed back to application vendors and standards organizations. This project is leveraging work ongoing in industry by forming a strategic partnership with PDES, Inc. and the Automotive Industry Action Group (AIAG). NIST has received a contract from the AIAG's AutoSTEP pilot project under the Defense Research Projects Agency's funding. AIAG partners are currently implementing and testing STEP throughout the automotive supply chain. AIAG has

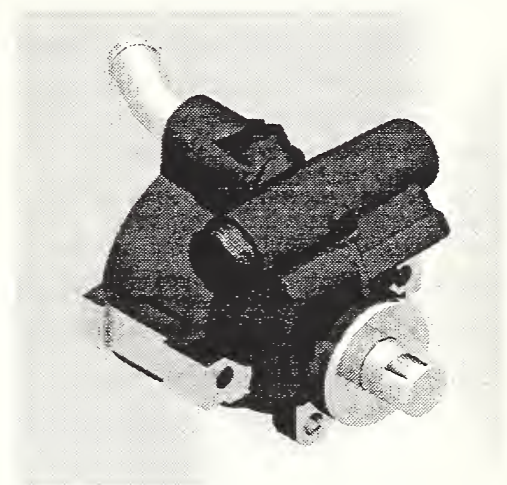

Model of supercharger used for testing STEP translators initiated the AutoSTEP pilot project to implement STEP in a production environment. NIST is providing its expertise on requirements analysis, STEP methodology, issue management, and STEP testing tools to the pilot team. NIST-developed software will be extended where needed to meet the demands of the pilot and this technology will be transferred to pilot members to accelerate commercial implementations and their use by industry. NIST is uniquely positioned to provide the needed interface between pilot implementation projects and the STEP development community. In accordance with its traditional role, NIST will act as a neutral party to convene implementor forums between key industry users and the vendor community to develop recommendations for the rapid resolution of problems related to the practical implementation of STEP. NIST has established a neutral site for Internet communications between AutoSTEP pilot project members. NIST will facilitate modifications to STEP and STEP methods by communicating implementation issues and building consensus towards their resolution within the STEP development community. By extending the STEP methods in support of implementations and by establishing implementation guidelines, the use of STEP will be accelerated as an advanced manufacturing technology.

7. Formerly known as the "STEP Implementations" project. 


\section{FY96 Accomplishments}

- Published interoperability requirements analysis for AIAG AutoSTEP project - NISTIR 5844.

- Published STEP CAD interoperability methodology guidelines - NISTIR 5794.

- Published solid model exchange procedures for AIAG AutoSTEP project - NISTIR 5833.

- Released NIST Toolkit and Conformance Testing software to STEP pilot teams - conformance testing software developed by NIST was released to project participants to help STEP product vendors evaluate how well their products conform to the standard.

- Maintained reporting system and database of model exchange issues for AutoSTEP project.

- Established automated STEP file online testing service at NIST for AutoSTEP members.

- Provided training on STEP and NIST software tools that will be used in the project.

- Facilitated the STEP Implementor's Forum for the discussion of issues with vendors.

- Organized and conducted workshops for STEP implementors.

- Developed STEP training course materials and transferred to Electronic Commerce Resource Centers (train the trainer program).

Collaborations

- Allied Signal, for participation in the AutoSTEP Supply Chain Integration project as a first tier supplier.

- Automotive Industry Action Group (AIAG), for work in the AutoSTEP Supply Chain Integration project.

- Chrysler Corp., for participation in the AutoSTEP Supply Chain Integration project as an automotive original equipment manufacturer.

- Dana, for participation in the AutoSTEP Supply Chain Integration project as a first tier supplier.

- Delphi Saginaw, for participation in the AutoSTEP Supply Chain Integration project as a first tier supplier.

- Eaton, for participation in the AutoSTEP Supply Chain Integration project as a first tier supplier.

- Ford Motor Company/Powertrain Division, for participation in the AutoSTEP Supply Chain Integration project as an automotive original equipment manufacturer.

- General Dynamics/Land Systems Division, for participation in the AutoSTEP Supply Chain Integration project as a defense sector original equipment manufacturer.

- General Motors Corporation/Truck Division, for participation in the AutoSTEP Supply Chain Integration project as an automotive original equipment manufacturer.

- Industrial Technology Institute (ITI), for development of STEP conformance testing software and provision of STEP testing method expertise.

- Nypro, for participation in the AutoSTEP Supply Chain Integration project as a second tier supplier.

- PDES, Inc., for development of software tools, standards coordination, issues reporting, and training.

- Shellcast, for participation in the AutoSTEP Supply Chain Integration project as a second tier supplier.

- SPX, for participation in the AutoSTEP Supply Chain Integration project as a second tier supplier.

- TRW, for participation in the AutoSTEP Supply Chain Integration project as a supplier.

- United Defense Limited Partners (UDLP), for participation in the AutoSTEP Supply Chain Integration project as a defense sector original equipment manufacturer. 


\section{Testbeds and Technology Transfer Environment Project Summaries TTTE1: Advanced Manufacturing Systems and Networking Testbed 8}

Project Manager: Robert Densock

Telephone: (301) 975 - 6546

E-mail: densock@nist.gov

Project Manager: Michelle Potts Steves

Telephone: (301) 975 - 3537

E-mail: msteves@cme.nist.gov

The objective of the Advanced Manufacturing Systems and Networking Testbed (AMSANT) project is to provide a distributed, multinode facility offering advanced computing and communications infrastructure with advanced digital library services thereby enabling collaborative development of specifications which support distributed and virtual manufacturing enterprises.

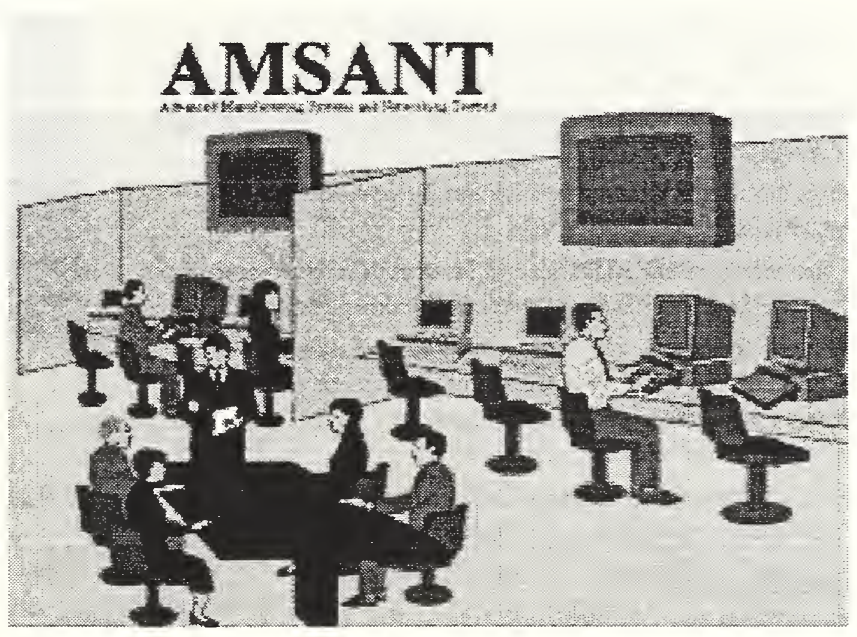

\section{FY96 Accomplishments}

- Performed annual AMSANT requirements survey of SIMA projects. FY96 hardware and software purchases completed based on analysis of project requirements.

- Performed requirements gathering and analysis for new National Advanced Manufacturing Testbed (NAMT) facility. Designed and implemented facility infrastructure in accordance with requirements.

- Designed configuration of fiber optic cable system linking AMSANT and NAMT facilities. Completed installation and linkages to existing network infrastructure.

- Transitioned web training activities, web page creation, and web support services to other individual projects and organizations as appropriate.

- Established automatic web page update capabilities based on publication database.

- Extended prototype of NIST Identifier Collaboration Service enabling internet-based collaborations on development of identifier dictionaries.

- Identified requirements for desktop-based video conferencing capabilities. Acquired and tested potential solutions. 


\section{TTTE2: Analysis Tools for Assessment and Optimization of Process and Product Design}

Project Manager: James Filliben

Telephone: (301) 975 - 2855

E-mail: filliben@cam.nist.gov

The objective of this project is to develop an integrated computer environment which provides a design/manufacturing engineer immediate on-line access to those statistical analysis tools necessary for characterizing, modeling, monitoring, and optimizing a process or product. This is achieved by creating an engineering-friendly, integrated system with the following capabilities:

- ready access to an on-line "statistics for engineering" handbook with state-of-the-art discussion/exposition of statistical solutions for everyday engineering problems,

- an on-line translator which maps engineering problems into appropriate statistical counterparts,

- an on-line solver which identifies via its structure what the optimal statistical methodology is for a given engineering problem,

- an on-line environment which has seamless and simultaneous access to both the engineer's data and to an appropriate analysis engine so as to automatically and immediately apply the correct methodology to the engineer's data, and

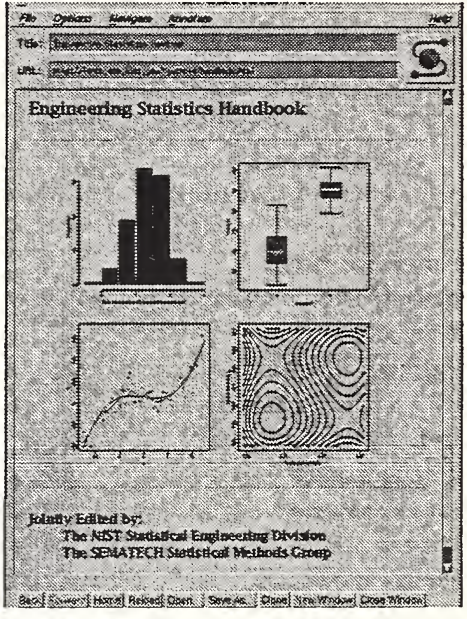

Web interface to handbook

- an on-line interpreter which translates the output of the statistical methodology tools into conclusions which are significant and meaningful to the engineer.

\section{FY96 Accomplishments}

- Augmented Dataplot statistical software engine for easier access from Windows and Windows NT platforms.

- Developed draft version of revised Dataplot statistical software reference manual. Tested options for transforming the manual into an internet-accessible version.

- Implemented a prototype version of an on-line "graphics gallery" providing a resource for common graphical data analysis techniques referred to and recommended during handbook usage.

- Implemented an initial on-line resource consisting of frequently-asked-questions on Dataplot usage.

- Implemented an initial version of an on-line glossary to reduce terminology ambiguities which may arise between statistical and engineering disciplines.

- Developed and evaluated alternatives in the handbook organization, structure, and visual design.

- Implemented prototype versions of parts of selected chapters to identify issues of dynamics and navigation.

- Developed a compact navigation bar and uniform layout to apply to all handbook pages.

- Converted prototype handbook text, equation, and graphics input from multiple platform sources. Evaluated different text to hypertext markup language (HTML) processing systems. Started investigation to allow direct HTML entry via HTML template to obviate conversion problems and increase flexibility and uniformity of page appearance.

\section{Collaborations}

- SEMATECH, to co-author the Engineering Statistics Handbook. 


\section{$\underline{\text { Standard Reference Data Delivery and Use Projects }}$}

Project Coordinator: Phoebe Fagan

Telephone: (301) 975 - 2213

E-mail: phoebe.fagan@ nist.gov

Critical decisions in manufacturing and engineering depend on reliable data. The NIST Standard Reference Data Program (SRDP) provides numeric data critically evaluated in data centers throughout the NIST laboratories. The thrust of this group of SIMA projects is to make that data more readily available to engineers and scientists in U.S. industry. The breadth of the NIST data program and the diverse expectations of the industrial community require that NIST provide tools to help users find the data they need. Project participants are creating ways to reuse existing structures and algorithms and generating new algorithms where necessary, in order to deliver existing and future NIST data so that the data are both accessible on-line to individuals and freely exchangeable among instruments. SIMA efforts are taking place in three NIST laboratories, the Chemical Science and Technology Laboratory, the Materials Science and Engineering Laboratory, and the Physics Laboratory. These SIMA efforts are coordinated and jointly supported by SRDP. The chemistry projects began in FY94. The physics lab began participating in FY95. The

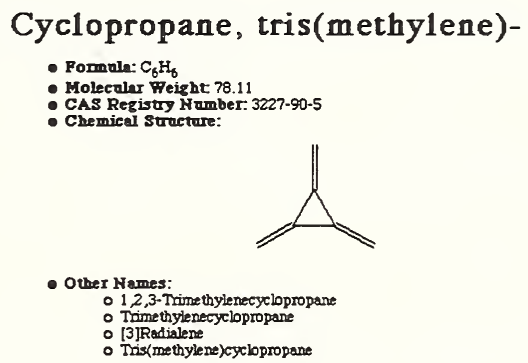

- Other Names:

o $1,2,3$-Thime thyienecyclopropane

- Trimethylenecyclopropane

- This(methylene)cycopropane

Thermochemical Data:

\begin{tabular}{|c|c|c|c|}
\hline & Falue & Unit & Sovrre \\
\hline$\Delta$ & 400 & $\mathrm{kJJ} / \mathrm{mol}$ & $82 R O S D A N$ \\
\hline
\end{tabular}

Ionization Potential Data:

Vare from NIST Critical ReTie (88LIASBAR): $(8.8) \mathrm{eq}$

Falue (eV) Method Source

\begin{tabular}{|c|c|c|}
\hline $9.0 \pm 0.1$ & $\underline{\mathbf{S}}$ & $7 \triangle \mathrm{DOR} I S C H$ \\
\hline $8.94(\mathrm{C})$. & pE & $78 \mathrm{BALMAS}$ \\
\hline $8.94 \pm 0.02(\overline{7})$. & $\underline{P E}$ & $77 B$ IRIBUR \\
\hline
\end{tabular}

Explanation of rems and codes

Literature References:

82ROSIDAN

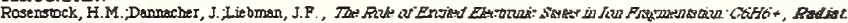

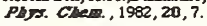

88LIAIBAR:

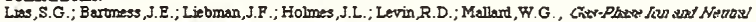

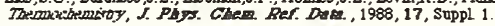

74DORISCH:

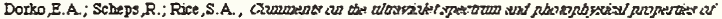

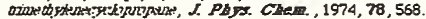

78BAL/HAS:

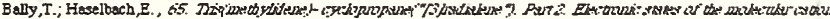

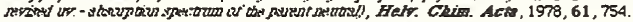

77BIE/BUR:

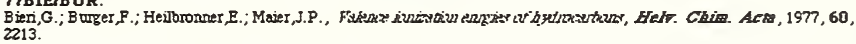

Sample selection from NIST Chemistry WebBook materials efforts began in FY96. Accomplishments for this collection of projects are grouped together at the end of this summary.

\section{TTTE3: Integration of NIST Standard Reference Data into Information Networks}

Project Manager: Edward Saloman

Telephone: (301) 975 - 5554

E-mail: edward.saloman@nist.gov

The objective of this project is to make physical reference data available via the internet and in so doing demonstrate a prototypical framework for making the full range of scientific and engineering information available to application systems. 


\section{TTTE4: NIST Informatics Web Site Supporting Advanced Ceramics Applications 9}

Project Manager: Ed Begley

Telephone: (301) 975 - 6118

E-mail: edwin.begley@nist.gov

The objective of this project is to make the NIST High Temperature Superconductors Database available via the internet and to identify industry needs and potential NIST solutions with respect to use of reference data in computeraided engineering.

\section{TTTE5: Online Access to NIST Chemical Reference Data}

Project Manager: Gary Mallard

Telephone: (301) 975 - 2564

E-mail: gary.mallard@nist.gov

The objective of this project is to make NIST chemical reference data available via the internet and to develop the tools and mechanisms necessary to make all NIST chemical data uniformly accessible.

\section{TTTE6: Standards for Exchange of Instrument Data and NIST Chemical Reference Data}

Project Manager: Gary Kramer

Telephone: (301) 975 - 4132

E-mail: gary.kramer@nist.gov

The objective of this project is to develop the models and mechanisms supporting data interchange in analytical chemistry instruments.

\section{FY96 Accomplishments}

- Developed an internet-accessible version of a bibliographic database of photon total cross section (attenuation coefficient) measurements.

- Developed an internet-accessible version of a database of critically evaluated transition frequencies for the molecular transitions detected in interstellar and circumstellar clouds in the microwave and millimeter wavelength regions.

- Held Computer Integrated Knowledge Systems Network for High Performance Construction Materials and Systems Workshop to identify industry needs for materials information.

- Developed the internet-accessible "NIST Chemistry WebBook" allowing multiple search mechanisms for physical property data and providing the chemical structure drawings for unique chemical substance identification.

- Demonstrated prototype analytical instrument control using initial instrument capability dataset and high level communications on laboratory automation system testbed.

- Revised draft of "Laboratory Equipment Control Interface Specification" submitted to American Society for Testing and Materials (ASTM) Subcommittee E49.52.

9. Formerly known as the "WWW Access to High Temperature Superconductors" and the "Use of NIST Standard Reference Databases in Computer-Assisted Engineering" projects. 


\section{Collaborations}

- Dow Chemical, for development of chemical property prediction techniques.

- Harvard Smithsonian Center for Astrophysics, for development of the atomic spectroscopic database.

- Los Alamos National Laboratory, for development of analytical instrument capability datasets.

- National Research Institute for Metals, for evaluation of data for high-temperature superconductors.

- Pacific Northwest National Laboratory, for development of chemical property prediction techniques.

- Team Science, Inc., for development of models for analytical data interchange.

- University of Maryland - Baltimore County, for development of data for chemical thermodynamics.

- University of Tennessee, for development of data for ion thermochemistry.

- Wiesbaden Polytechnic, for development of laboratory automation specifications. 


\section{Conclusion}

The premise of the SIMA Program is that the numerous software systems used in design and manufacturing processes do not allow for exchange of information as well as is required. The SIMA Program's project leaders work with their industrial partners to identify information needs among manufacturing enterprise activities and in what contexts, to identify information representation issues between the software systems used in those activities, and to define mechanisms appropriate to resolve those issues. By maintaining a neutral perspective in the testing of information interfaces for engineering and manufacturing, the Program ensures that validated solutions addressing the common requirements of both users and software providers can be adopted.

\section{References}

[1] "Technical Program Description Systems Integration for Manufacturing," Bloom, H., NISTIR 5476, NIST, Gaithersburg, MD, July 1994.

[2] "Systems Integration for Manufacturing Applications Technical Program Plan," Fowler, J., NISTIR 5986, NIST, Gaithersburg, MD, March 1997.

[3] "Systems Integration for Manufacturing Applications Program 1995 Annual Report," Fowler, J., Luce, M., NISTIR 5839, Gaithersburg, MD, May 1996.

[4] ISO 10303-1, "Industrial automation systems and integration - Product data representation and exchange Part 1: Overview and fundamental principles," International Organization for Standardization, Geneva, Switzerland.

[5] "High Performance Computing and Communications: Toward a National Information Infrastructure," Report by the Committee on Physical, Mathematical, and Engineering Sciences, Federal Coordinating Council for Science, Engineering, and Technology, Office of Science and Technology Policy, published by the National Coordination Office for HPCC, 1994.

[6] "Information Infrastructure Technology and Applications," Report of the IITA Task Group, High Performance Computing, Communications and Information Technology Subcommittee, Federal Coordinating Council for Science, Engineering, and Technology, Office of Science and Technology Policy, published by the National Coordination Office for HPCC, February 1994.

[7] "HPCC FY95 Implementation Plan," Office of Science and Technology Policy, published by the National Coordination Office for HPCC, April 1994.

[8] "High Performance Computing and Communications: Advancing the Frontiers of Information Technology," Report by the Committee on Computing, Information, and Communications, National Science and Technology Council, published by the National Coordination Office for Computing, Information, and Communications, 1996.

[9] "Initial Manufacturing Exchange Specification (IMES) Concept Document For Manufacturing Systems Integration,” Kemmerer, S., Fowler, J., ed., NISTIR 5978, NIST, Gaithersburg, MD, February 1997. 


\section{Appendix A: Program Organization}

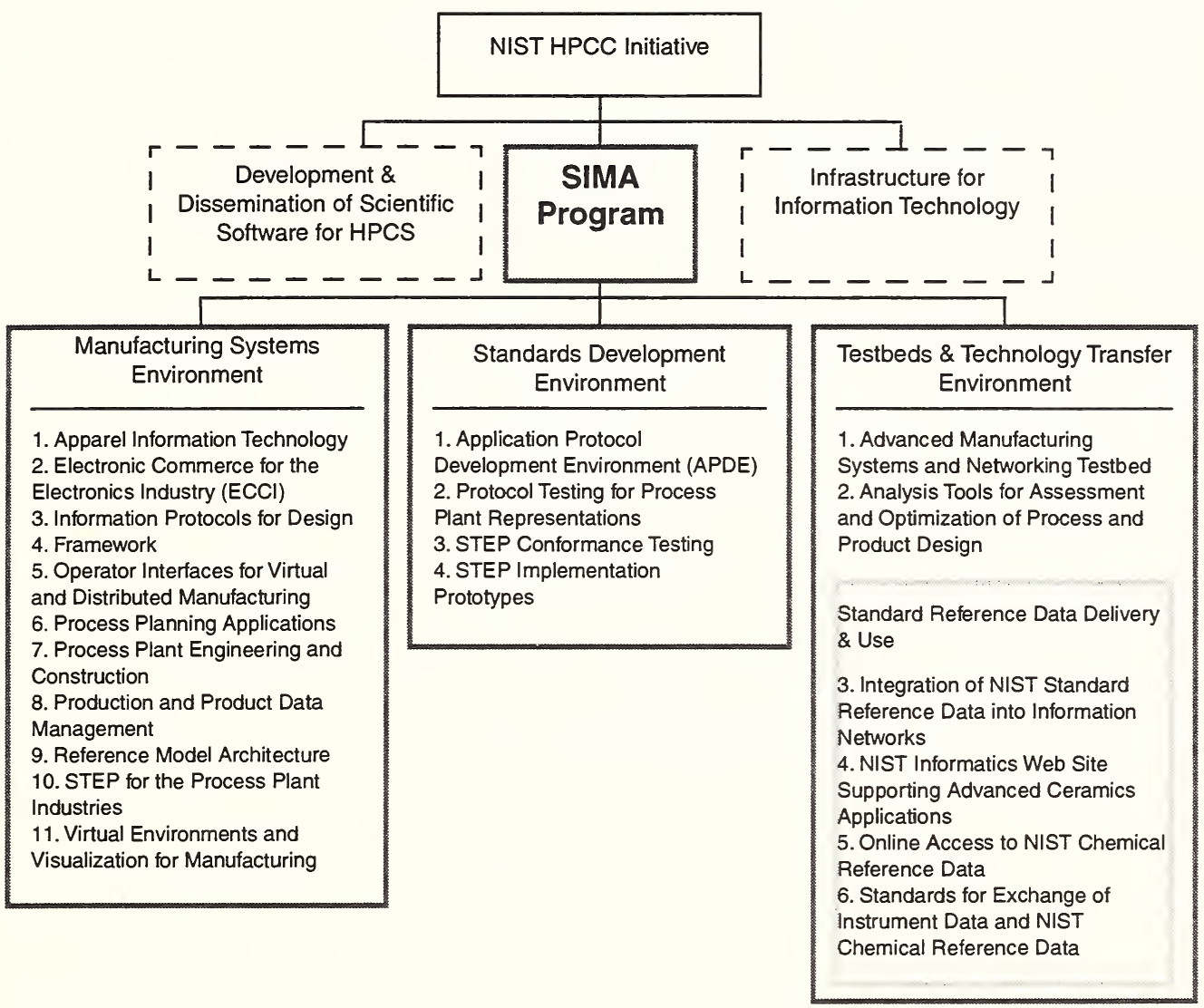

Figure 3. Organization of the NIST HPCC Initiative

The SIMA Program was one of three HPCC initiative efforts underway at NIST in FY96 (see Figure 3). The SIMA Program is directed by a manager in the Manufacturing Systems Integration Division (MSID) of NIST's Manufacturing Engineering Laboratory (MEL). Individual SIMA projects are led by NIST research staff. All of NIST's intramural laboratory units participate in the SIMA Program. The following descriptions briefly summarize the mission of each participating NIST organization ${ }^{1}$.

1. More information about NIST Laboratories can be found at http://www.nist.gov/labs2.html. 


\section{Building and Fire Research Laboratory (BFRL)}

The BFRL works to enhance the competitiveness of U.S. industry and public safety through performance prediction and measurement technologies and technical advances that improve the lifecycle quality of constructed facilities.

\section{Chemical Science and Technology Laboratory (CSTL)}

As the Nation's Reference Laboratory, the CSTL performs cutting edge research in measurement science. The Laboratory develops and maintains measurement methods, standards, and reference data; and develops models for chemical, biochemical, and physical properties and processes.

\section{Information Technology Laboratory (ITL)}

The ITL develops, demonstrates, and supplies high quality information technology, metrology, and standards that enable U.S. industry to develop usable, reliable, interoperable products. In doing so, the ITL serves as a neutral agent to accelerate acceptance and use of information technology that will promote economic competitiveness and the public good. The ITL provides leadership and collaborative research to NIST programs in the areas of mathematics, statistics, and information technology use and services to enable NIST to maintain its status as a world class institution.

\section{Electronic and Electrical Engineering Laboratory (EEEL)}

The EEEL promotes U.S. economic growth through improved international competitiveness, by providing measurement capability of high economic impact focused primarily on the critical needs of the U.S. electronics and electrical-equipment industries.

\section{Manufacturing Engineering Laboratory (MEL)}

The MEL works to improve the competitiveness of U.S. manufacturing by working with industry to develop and apply infrastructural technology, measurements, and standards.

\section{Material Science and Engineering Laboratory (MSEL)}

The MSEL works to stimulate the more effective production and use of materials by working with materials suppliers and users to assure the development and implementation of the measurements and standards infrastructure for materials.

\section{Physics Laboratory (PL)}

The PL supports U.S. industry by providing measurement services and research for electronic, optical, and radiation technology.

\section{Technology Services (TS)}

TS provides a wide variety of services and programs to help U.S. industry improve its international competitiveness. TS supplies NIST reference materials, data, and calibrations to help industry maintain production quality control. TS also provides information and assistance concerning national and international voluntary and regulatory product standards and certification systems.

\section{Program Components}

To align the resources of the program with the needs defined by industry, the SIMA Program has been organized into three program areas. The program areas are known as: (1) Manufacturing Systems Environment, (2) Standards Development Environment, and (3) Testbed and Technology Transfer Environment. Activities within each area satisfy a unique NIST role in support of the HPCC goals and address the major technology and standards issues outlined in the IITA program report [6]. The focus of each of the three program areas is described below. 


\section{Manufacturing Systems Environment (MSE)}

The objectives of this environment are to develop integration technologies and standards in support of a broad range of industrial manufacturing domains that include mechanical products, apparel, electronics, construction, and chemical processing. The application systems of interest within these domains include design (product, process, and enterprise), planning, scheduling, process modeling, shop control, simulation, inspection, assembly, and machining. The problem scope includes manufacturing systems integration both within and among multiple enterprises. The MSE projects focus on the development of infrastructure technologies, interface protocols, and information models with the intention of applying these integration solutions to application system incompatibilities. Typical integration and interface technology solutions include information protocols for product and process data, information repositories, and frameworks. The major result of MSE activities are integration specifications for manufacturing systems and prototype process models for use throughout the manufacturing environment.

\section{Standards Development Environment (SDE)}

The objectives of this environment are to assist industry in implementing voluntary consensus standards relevant to computer integrated manufacturing (CIM), facilitate industry efforts to test evolving information exchange and interface specifications utilizing internet technology, and accelerate industry deployment of consensus standards. There is a general theme of providing effective support environments for the development of standards as well as facilitating the harmonization across the broad spectrum of standards that compose the range of information and supporting technology required for enterprise integration.

\section{Testbeds and Technology Transfer Environment (TTTE)}

The objectives of this environment are to develop technology transfer infrastructure which can be used to disseminate Program results using internet technology, to develop prototype information services in collaboration with industry partners which could become commercialized products, to develop services related to document searches and retrieval of government and other research reports, and to establish communication channels for researchers and implementors of manufacturing technologies. Testbeds developed under the auspices of TTTE are intended to serve as collaborative testing and demonstration sites as well as to serve as the focal points for information dissemination. 


\begin{tabular}{|c|c|c|c|}
\hline \multicolumn{4}{|c|}{ Consortia, National Programs, Professional and Trade Associations } \\
\hline Name & Location & Description & $\begin{array}{l}\text { Collaborating } \\
\text { Project }\end{array}$ \\
\hline $\begin{array}{l}\text { American Institute of Steel } \\
\text { Construction }\end{array}$ & $\begin{array}{l}\text { Chicago, } \\
\text { IL }\end{array}$ & $\begin{array}{l}\text { The American Institute of Steel Construction is a non- } \\
\text { profit trade organization that represents the fabricated } \\
\text { steel industry of the United States. The Institute's objec- } \\
\text { tives are to improve and advance the use of fabricated } \\
\text { structural steel through research and engineering studies } \\
\text { to develop the most efficient and economical design of } \\
\text { structures. It also conducts programs to improve product } \\
\text { quality. }\end{array}$ & $\begin{array}{l}\text { Process Plant } \\
\text { Engineering } \\
\text { and Construc- } \\
\text { tion (p. 22). }\end{array}$ \\
\hline $\begin{array}{l}\text { Automotive Industry Action } \\
\text { Group (AIAG) }\end{array}$ & $\begin{array}{l}\text { Southfield, } \\
\text { MI }\end{array}$ & $\begin{array}{l}\text { The AIAG is an automotive trade association addressing } \\
\text { industry issues in supply, manufacturing, engineering, } \\
\text { quality, and finance. The association has over } 1000 \\
\text { member companies and includes Chrysler, Ford, and } \\
\text { General Motors. }\end{array}$ & $\begin{array}{l}\text { STEP Imple- } \\
\text { mentation Pro- } \\
\text { totypes (p. 35). }\end{array}$ \\
\hline $\begin{array}{l}\text { CAD Framework Initiative, } \\
\text { Inc. }\end{array}$ & Austin, TX & $\begin{array}{l}\text { CFI, Inc. is an international not-for-profit consortium } \\
\text { whose mission is to facilitate and promote the adoption } \\
\text { of open electronic design automation technologies } \\
\text { which improve designer productivity. CFI's membership } \\
\text { includes over } 40 \text { companies comprised of electronic } \\
\text { design automation designers and suppliers of high per- } \\
\text { formance semi-custom silicon in North America, } \\
\text { Europe, and Asia. }\end{array}$ & $\begin{array}{l}\text { Electronic Com- } \\
\text { merce for the } \\
\text { Electronics } \\
\text { Industry } \\
\text { (ECCI) (p. 13). }\end{array}$ \\
\hline $\begin{array}{l}\text { Electronics Industries Associa- } \\
\text { tion (EIA) }\end{array}$ & $\begin{array}{l}\text { Arlington, } \\
\text { VA }\end{array}$ & $\begin{array}{l}\text { The EIA is a trade association representing the U.S. high } \\
\text { technology community. EIA has created a host of activi- } \\
\text { ties to enhance the competitiveness of the American pro- } \\
\text { ducer including such valuable services as technical } \\
\text { standards development, market analysis, government } \\
\text { relations, trade shows and seminar programs. }\end{array}$ & $\begin{array}{l}\text { Electronic Com- } \\
\text { merce for the } \\
\text { Electronics } \\
\text { Industry } \\
(\mathrm{ECCI}) \text { (p. 13). }\end{array}$ \\
\hline $\begin{array}{l}\text { Footwear Industries of America } \\
\text { (FIA) }\end{array}$ & $\begin{array}{l}\text { Washing- } \\
\text { ton, DC }\end{array}$ & $\begin{array}{l}\text { The FIA is a trade association working to make the } \\
\text { American footwear industry more competitive in the } \\
\text { global market and to serve as an information resource for } \\
\text { the industry. It has over } 150 \text { members including most of } \\
\text { the large shoe manufacturers and suppliers to the indus- } \\
\text { try. }\end{array}$ & $\begin{array}{l}\text { Apparel Infor- } \\
\text { mation Technol- } \\
\text { ogy (p. 12). }\end{array}$ \\
\hline $\begin{array}{l}\text { International Society of Mea- } \\
\text { surement and Control }\end{array}$ & $\begin{array}{l}\text { Research } \\
\text { Triangle } \\
\text { Park, NC }\end{array}$ & $\begin{array}{l}\text { A non-profit engineering society advancing the technol- } \\
\text { ogy, and the competence and careers of practitioners } \\
\text { worldwide. }\end{array}$ & $\begin{array}{l}\text { STEP for the } \\
\text { Process Plant } \\
\text { Industries (p. } \\
\text { 28). }\end{array}$ \\
\hline
\end{tabular}




\begin{tabular}{|c|c|c|c|}
\hline \multicolumn{4}{|c|}{ Consortia, National Programs, Professional and Trade Associations } \\
\hline Name & Location & Description & $\begin{array}{l}\text { Collaborating } \\
\text { Project }\end{array}$ \\
\hline $\begin{array}{l}\text { National Industrial Informa- } \\
\text { tion Infrastructure Protocols } \\
\text { (NIIIP) }\end{array}$ & $\begin{array}{l}\text { Stamford, } \\
\text { CT }\end{array}$ & $\begin{array}{l}\text { The NIIIP consortium's objective is to develop open } \\
\text { industry software protocols that will make it possible for } \\
\text { manufacturers and their suppliers to effectively interop- } \\
\text { erate as if they were part of the same enterprise. The } \\
\text { consortium includes IBM, Digital Equipment Corpora- } \\
\text { tion, Enterprise Integration Technologies, General } \\
\text { Dynamics, Lockheed Aeronautical Systems, Magnavox, } \\
\text { Texas Instruments, and other participants. }\end{array}$ & $\begin{array}{l}\text { Framework (p. } \\
17) .\end{array}$ \\
\hline $\begin{array}{l}\text { Next Generation Inspection } \\
\text { System Program }\end{array}$ & $\begin{array}{l}\text { Ann } \\
\text { Arbor, MI }\end{array}$ & $\begin{array}{l}\text { NGIS is a program of the National Center for Manufac- } \\
\text { turing Sciences, Production Equipment and Systems } \\
\text { Special Interest Group. The objective is to develop next } \\
\text { generation inspection capabilities on coordinate measur- } \\
\text { ing machines and machine tools. }\end{array}$ & $\begin{array}{l}\text { Reference } \\
\text { Model Architec- } \\
\text { ture (p. 26). }\end{array}$ \\
\hline PDES, Inc. & $\begin{array}{l}\text { Charles- } \\
\text { ton, SC }\end{array}$ & $\begin{array}{l}\text { The PDES, Inc. consortium's objective is to accelerate } \\
\text { the development and implementation of STEP. The con- } \\
\text { sortium includes the South Carolina Research Authority, } \\
\text { Boeing, Ford, General Motors, Hughes, Lockheed Mar- } \\
\text { tin, Northrop Grumman, and other participants. }\end{array}$ & $\begin{array}{l}\text { Electronic Com- } \\
\text { merce for the } \\
\text { Electronics } \\
\text { Industry } \\
\text { (ECCI) (p. 13). } \\
\text { Process Plan- } \\
\text { ning Applica- } \\
\text { tions (p. 20). } \\
\text { STEP Conform- } \\
\text { ance Testing (p. } \\
\text { 33). } \\
\text { STEP Imple- } \\
\text { mentation Pro- } \\
\text { totypes (p. 35). }\end{array}$ \\
\hline $\begin{array}{l}\text { Pedorthic Footwear Associa- } \\
\text { tion (PFA) }\end{array}$ & $\begin{array}{l}\text { Columbia, } \\
\text { MD }\end{array}$ & $\begin{array}{l}\text { The PFA represents both retail and manufacturing seg- } \\
\text { ments of the pedorthic profession. Members share inter- } \\
\text { est in pedorthic management of the foot from practice } \\
\text { and treatment to education and research. }\end{array}$ & $\begin{array}{l}\text { Apparel Infor- } \\
\text { mation Technol- } \\
\text { ogy (p. 12). }\end{array}$ \\
\hline $\begin{array}{l}\text { PIEBASE (Process Industry } \\
\text { Executive for achieving } \\
\text { Business Advantage using } \\
\text { Standards for data } \\
\text { Exchange) }\end{array}$ & $\begin{array}{l}\text { London, } \\
\text { England }\end{array}$ & $\begin{array}{l}\text { PIEBASE is a global umbrella that coordinates develop- } \\
\text { ment and implementation of data exchange and data } \\
\text { sharing standards for the process plant industry consortia } \\
\text { and member companies. }\end{array}$ & $\begin{array}{l}\text { STEP for the } \\
\text { Process Plant } \\
\text { Industries (p. } \\
\text { 28). }\end{array}$ \\
\hline PlantSTEP, Inc. & $\begin{array}{l}\text { Wilming- } \\
\text { ton, DE }\end{array}$ & $\begin{array}{l}\text { PlantSTEP, Inc. is a consortium working to support the } \\
\text { development of information exchange standards to } \\
\text { advance the capabilities of process plant and construc- } \\
\text { tion industries. Members include DuPont, Merck, Black } \\
\& \text { Veach, Bechtel, Intergraph, Computervision, and } \\
\text { CAD Centre. }\end{array}$ & $\begin{array}{l}\text { STEP for the } \\
\text { Process Plant } \\
\text { Industries (p. } \\
\text { 28). } \\
\text { Protocol Test- } \\
\text { ing for Process } \\
\text { Plant Represen- } \\
\text { tations (p. 32). }\end{array}$ \\
\hline
\end{tabular}




\begin{tabular}{|c|c|c|c|}
\hline \multicolumn{4}{|c|}{ Consortia, National Programs, Professional and Trade Associations } \\
\hline Name & Location & Description & $\begin{array}{l}\text { Collaborating } \\
\text { Project }\end{array}$ \\
\hline $\begin{array}{l}\text { Process Data eXchange Insti- } \\
\text { tute of AIChE (pdXi) }\end{array}$ & $\begin{array}{l}\text { New York, } \\
\text { NY }\end{array}$ & $\begin{array}{l}\text { pDXI is an industry trade group working to develop and } \\
\text { maintain open approaches to electronic data exchange } \\
\text { and management of process engineering data. Members } \\
\text { include DuPont, Exxon, and Simulation Sciences, Union } \\
\text { Carbide, and others. }\end{array}$ & $\begin{array}{l}\text { STEP for the } \\
\text { Process Plant } \\
\text { Industries (p. } \\
\text { 28). }\end{array}$ \\
\hline Rapid Response Manufacturing & $\begin{array}{l}\text { Ann } \\
\text { Arbor, MI }\end{array}$ & $\begin{array}{l}\text { The RRM consortium's objective is to increase first } \\
\text { product quality while decreasing design to manufactur- } \\
\text { ing cycle time. The RRM consortium includes the } \\
\text { National Center for Manufacturing Sciences (NCMS), } \\
\text { General Motors, Ford Motor, Texas Instruments, United } \\
\text { Technologies, Lockheed Martin Energy Systems, and } \\
\text { other participants. }\end{array}$ & $\begin{array}{l}\text { Production and } \\
\text { Product Data } \\
\text { Management } \\
\text { (p. 23). }\end{array}$ \\
\hline SEMATECH & Austin, TX & $\begin{array}{l}\text { The SEMATECH consortium's objective is to sponsor } \\
\text { and conduct research aimed at assuring leadership in } \\
\text { semiconductor manufacturing technology for the U.S. } \\
\text { semiconductor industry. The consortium includes } \\
\text { Advanced Micro Devices, Digital Equipment Corpora- } \\
\text { tion, Hewlett-Packard, Intel, IBM, Lucent Technologies, } \\
\text { Motorola, National Semiconductor Corporation, Rock- } \\
\text { well International, and Texas Instruments. }\end{array}$ & $\begin{array}{l}\text { Electronic Com- } \\
\text { merce for the } \\
\text { Electronics } \\
\text { Industry } \\
\text { (ECCI) (p. 13). } \\
\text { Framework (p. } \\
\text { 17). } \\
\text { Production and } \\
\text { Product Data } \\
\text { Management } \\
\text { (p. 23). } \\
\text { Analysis Tools } \\
\text { for Assessment } \\
\text { and Optimiza- } \\
\text { tion of Process } \\
\text { and Product } \\
\text { Design (p. 38). }\end{array}$ \\
\hline $\begin{array}{l}\text { Technologies Enabling Agile } \\
\text { Manufacturing (TEAM) }\end{array}$ & $\begin{array}{l}\text { Oak } \\
\text { Ridge, TN }\end{array}$ & $\begin{array}{l}\text { The TEAM consortium's objective is to enhance } \\
\text { national industrial competitiveness by advancing and } \\
\text { deploying manufacturing technologies that promote agil- } \\
\text { ity. The consortium includes American firms and consor- } \\
\text { tia representing many industrial sectors including } \\
\text { aerospace, automotive, consumer electronics, and soft- } \\
\text { ware along with multiple federal agencies and facilities. }\end{array}$ & $\begin{array}{l}\text { Framework (p. } \\
\text { 17). } \\
\text { Process Plan- } \\
\text { ning Applica- } \\
\text { tions (p. 20). } \\
\text { Production and } \\
\text { Product Data } \\
\text { Management } \\
\text { (p. 23). } \\
\text { Reference } \\
\text { Model Architec- } \\
\text { ture (p. 26). }\end{array}$ \\
\hline
\end{tabular}




\begin{tabular}{|c|c|c|c|}
\hline \multicolumn{4}{|c|}{ Individual Companies } \\
\hline Name & Location & Description & $\begin{array}{l}\text { Collaborating } \\
\text { Project }\end{array}$ \\
\hline Adra Systems, Inc. & $\begin{array}{l}\text { Chelms- } \\
\text { ford, MA }\end{array}$ & $\begin{array}{l}\text { Vendor of information management and computer-aided } \\
\text { design software. }\end{array}$ & $\begin{array}{l}\text { Production and } \\
\text { Product Data } \\
\text { Management } \\
\text { (p. 23). }\end{array}$ \\
\hline $\begin{array}{l}\text { Advanced Technology and } \\
\text { Research Corporation }\end{array}$ & $\begin{array}{l}\text { Burtons- } \\
\text { ville, MD }\end{array}$ & $\begin{array}{l}\text { Consultants specializing in research and development of } \\
\text { intelligent control systems, automation, robotics, simula- } \\
\text { tion, engineering analysis, and computer science. }\end{array}$ & $\begin{array}{l}\text { Reference } \\
\text { Model Architec- } \\
\text { ture (p. 26). }\end{array}$ \\
\hline $\begin{array}{l}\text { Allied Signal Filters and Spark- } \\
\text { plugs Division }\end{array}$ & $\begin{array}{l}\text { Perrys- } \\
\text { burg, } \mathrm{OH}\end{array}$ & $\begin{array}{l}\text { Manufacturer of fuel filters and spark plugs for the auto- } \\
\text { motive, marine, aviation, and heavy equipment indus- } \\
\text { tries. }\end{array}$ & $\begin{array}{l}\text { STEP Imple- } \\
\text { mentation Pro- } \\
\text { totypes (p. } 35 \text { ) }\end{array}$ \\
\hline AMP, Incorporated & $\begin{array}{l}\text { Harris- } \\
\text { burg, PA }\end{array}$ & Manufacturer of electronic connectors. & $\begin{array}{l}\text { Production and } \\
\text { Product Data } \\
\text { Management } \\
\text { (p. 23). }\end{array}$ \\
\hline AutoSimulation, Incorporated & $\begin{array}{l}\text { Bountiful, } \\
\text { UT }\end{array}$ & Vendor of simulation and scheduling software. & $\begin{array}{l}\text { Production and } \\
\text { Product Data } \\
\text { Management } \\
\text { (p. 23). }\end{array}$ \\
\hline Bernier and Associates, Inc. & $\begin{array}{l}\text { Topsfield, } \\
\text { MA }\end{array}$ & $\begin{array}{l}\text { Software consultants specializing in data collection and } \\
\text { analysis }\end{array}$ & $\begin{array}{l}\text { Application } \\
\text { Protocol Devel- } \\
\text { opment Envi- } \\
\text { ronment } \\
\text { (APDE) (p. 30). }\end{array}$ \\
\hline Black and Decker & $\begin{array}{l}\text { Towson, } \\
\text { MD }\end{array}$ & $\begin{array}{l}\text { Manufacturer of portable power tools and household } \\
\text { appliances. }\end{array}$ & $\begin{array}{l}\text { Production and } \\
\text { Product Data } \\
\text { Management } \\
\text { (p. 23). } \\
\text { Virtual Environ- } \\
\text { ments and Visu- } \\
\text { alization for } \\
\text { Manufacturing } \\
\text { (p. 29). }\end{array}$ \\
\hline $\begin{array}{l}\text { Boeing Commercial Airplane } \\
\text { Group }\end{array}$ & $\begin{array}{l}\text { Seattle, } \\
\text { WA }\end{array}$ & Manufacturer of commercial airplanes. & $\begin{array}{l}\text { Information } \\
\text { Protocols for } \\
\text { Design (p. 15). } \\
\text { STEP Conform- } \\
\text { ance Testing (p. } \\
\text { 33). }\end{array}$ \\
\hline $\begin{array}{l}\text { Boeing Defense and Space } \\
\text { Group }\end{array}$ & $\begin{array}{l}\text { Philadel- } \\
\text { phia, PA }\end{array}$ & $\begin{array}{l}\text { Boeing Defense \& Space Group is the military and space } \\
\text { arm of The Boeing Company. }\end{array}$ & $\begin{array}{l}\text { Production and } \\
\text { Product Data } \\
\text { Management } \\
\text { (p. 23). }\end{array}$ \\
\hline CAMAX & $\begin{array}{l}\text { Eugene, } \\
\text { OR }\end{array}$ & Vendor of computer-aided manufacturing software. & $\begin{array}{l}\text { Process Plan- } \\
\text { ning Applica- } \\
\text { tions (p. 20). }\end{array}$ \\
\hline
\end{tabular}




\begin{tabular}{|c|c|c|c|}
\hline \multicolumn{4}{|c|}{ Individual Companies } \\
\hline Name & Location & Description & $\begin{array}{l}\text { Collaborating } \\
\text { Project }\end{array}$ \\
\hline Caterpillar & Peoria, IL & Manufacturer of earth-moving equipment. & $\begin{array}{l}\text { Information } \\
\text { Protocols for } \\
\text { Design (p. 15). }\end{array}$ \\
\hline Chrysler Corporation & $\begin{array}{l}\text { Auburn } \\
\text { Hills, MI }\end{array}$ & Automobile manufacturer. & $\begin{array}{l}\text { STEP Imple- } \\
\text { mentation Pro- } \\
\text { totypes (p. } 35 \text { ). }\end{array}$ \\
\hline CIMx & $\begin{array}{l}\text { Cincinnati, } \\
\mathrm{OH}\end{array}$ & $\begin{array}{l}\text { Vendor of software systems for discrete manufacturing } \\
\text { applications. }\end{array}$ & $\begin{array}{l}\text { Process Plan- } \\
\text { ning Applica- } \\
\text { tions (p. 20). }\end{array}$ \\
\hline CIM Technologies & Ames, IA & Vendor of plant layout software. & $\begin{array}{l}\text { Production and } \\
\text { Product Data } \\
\text { Management } \\
\text { (p. 23). }\end{array}$ \\
\hline CNC Software, Inc. & $\begin{array}{l}\text { Tolland, } \\
\text { CT }\end{array}$ & $\begin{array}{l}\text { Vendor of software tools for the CAD/CAM manufactur- } \\
\text { ing markets. }\end{array}$ & $\begin{array}{l}\text { Process Plan- } \\
\text { ning Applica- } \\
\text { tions (p. 20). }\end{array}$ \\
\hline $\begin{array}{l}\text { Concurrent Technologies Cor- } \\
\text { poration }\end{array}$ & $\begin{array}{l}\text { Johnstown, } \\
\text { PA }\end{array}$ & $\begin{array}{l}\text { A non-profit company chartered to take technology from } \\
\text { research labs to the commercial workplace. }\end{array}$ & $\begin{array}{l}\text { Application } \\
\text { Protocol Devel- } \\
\text { opment Envi- } \\
\text { ronment } \\
\text { (APDE) (p. 30). }\end{array}$ \\
\hline $\begin{array}{l}\text { D.H. Brown Associates } \\
\text { (DHBA) }\end{array}$ & $\begin{array}{l}\text { Port Ches- } \\
\text { ter, NY }\end{array}$ & $\begin{array}{l}\text { DHBA is a research analysis firm specializing in analy- } \\
\text { sis of technologies to support computer environments for } \\
\text { engineering, manufacturing, design, and open systems. }\end{array}$ & $\begin{array}{l}\text { Information } \\
\text { Protocols for } \\
\text { Design (p. 15). }\end{array}$ \\
\hline $\begin{array}{l}\text { Dana Corporation Parish Divi- } \\
\text { sion }\end{array}$ & $\begin{array}{l}\text { Reading, } \\
\text { PA }\end{array}$ & $\begin{array}{l}\text { Manufacturer of drive shafts for the automotive, marine, } \\
\text { aviation, and heavy equipment industries. }\end{array}$ & $\begin{array}{l}\text { STEP Imple- } \\
\text { mentation Pro- } \\
\text { totypes (p. 35). }\end{array}$ \\
\hline $\begin{array}{l}\text { Dana Corporation Spicer Divi- } \\
\text { sion }\end{array}$ & $\begin{array}{l}\text { Toledo, } \\
\mathrm{OH}\end{array}$ & $\begin{array}{l}\text { Manufacturer of drive shafts for the automotive, marine, } \\
\text { aviation, and heavy equipment industries. }\end{array}$ & $\begin{array}{l}\text { STEP Imple- } \\
\text { mentation Pro- } \\
\text { totypes (p. } 35 \text { ). }\end{array}$ \\
\hline Delco Electronics Corporation & $\begin{array}{l}\text { Kokomo, } \\
\text { IN }\end{array}$ & $\begin{array}{l}\text { Manufacturer of electrical components for the automo- } \\
\text { tive industry. }\end{array}$ & $\begin{array}{l}\text { STEP Imple- } \\
\text { mentation Pro- } \\
\text { totypes (p. } 35 \text { ). }\end{array}$ \\
\hline Delphi Saginaw & $\begin{array}{l}\text { Saginaw, } \\
\text { MI }\end{array}$ & Manufacturer of automotive body parts. & $\begin{array}{l}\text { STEP Imple- } \\
\text { mentation Pro- } \\
\text { totypes (p. } 35 \text { ). }\end{array}$ \\
\hline Deneb Robotics & $\begin{array}{l}\text { Auburn } \\
\text { Hills, MI }\end{array}$ & $\begin{array}{l}\text { Vendor of 3D graphics-based factory simulation, telero- } \\
\text { botic, and virtual reality software. }\end{array}$ & $\begin{array}{l}\text { Operator Inter- } \\
\text { faces for Virtual } \\
\text { and Distributed } \\
\text { Manufacturing } \\
\text { (p. 19). } \\
\text { Production and } \\
\text { Product Data } \\
\text { Management } \\
\text { (p. 23). }\end{array}$ \\
\hline
\end{tabular}




\begin{tabular}{|c|c|c|c|}
\hline \multicolumn{4}{|c|}{ Individual Companies } \\
\hline Name & Location & Description & $\begin{array}{l}\text { Collaborating } \\
\text { Project }\end{array}$ \\
\hline DiK Corporation & $\begin{array}{l}\text { Darmstadt, } \\
\text { Germany }\end{array}$ & $\begin{array}{l}\text { A university-based corporation specializing in automo- } \\
\text { tive design and analysis. }\end{array}$ & $\begin{array}{l}\text { Application } \\
\text { Protocol Devel- } \\
\text { opment Envi- } \\
\text { ronment } \\
\text { (APDE) (p. 30). }\end{array}$ \\
\hline DLOG Corporation & $\begin{array}{l}\text { Chicago, } \\
\text { IL }\end{array}$ & Vendor of shop floor data collection software. & $\begin{array}{l}\text { Production and } \\
\text { Product Data } \\
\text { Management } \\
\text { (p. } 23 \text { ). }\end{array}$ \\
\hline Dow Chemical Company & $\begin{array}{l}\text { Midland, } \\
\text { MI }\end{array}$ & $\begin{array}{l}\text { The Dow Chemical Company provides chemicals, plas- } \\
\text { tics, energy, agricultural products, consumer goods and } \\
\text { environmental services. }\end{array}$ & $\begin{array}{l}\text { Online Access } \\
\text { to NIST Chemi- } \\
\text { cal Reference } \\
\text { Data (p. 40). }\end{array}$ \\
\hline $\begin{array}{l}\text { Eaton Corporation Axle Divi- } \\
\text { sion }\end{array}$ & $\begin{array}{l}\text { Kalama- } \\
\text { zoo, MI }\end{array}$ & $\begin{array}{l}\text { Manufacturer of axles and steering components for the } \\
\text { automotive industry. }\end{array}$ & $\begin{array}{l}\text { STEP Imple- } \\
\text { mentation Pro- } \\
\text { totypes (p. 35). }\end{array}$ \\
\hline $\begin{array}{l}\text { Eaton Corporation Engine } \\
\text { Division }\end{array}$ & $\begin{array}{l}\text { Southfield, } \\
\text { MI }\end{array}$ & $\begin{array}{l}\text { Manufacturer of engine components for the automotive, } \\
\text { marine, aviation, and heavy equipment industries. }\end{array}$ & $\begin{array}{l}\text { STEP Imple- } \\
\text { mentation Pro- } \\
\text { totypes (p. 35). }\end{array}$ \\
\hline Ford Motor Company & $\begin{array}{l}\text { Dearborn, } \\
\text { MI }\end{array}$ & Automobile manufacturer. & $\begin{array}{l}\text { STEP Conform- } \\
\text { ance Testing (p. } \\
\text { 33). } \\
\text { STEP Imple- } \\
\text { mentation Pro- } \\
\text { totypes (p. 35). }\end{array}$ \\
\hline Framework Technologies & $\begin{array}{l}\text { Milwau- } \\
\text { kee, WI }\end{array}$ & Vendor of production simulation software. & $\begin{array}{l}\text { Production and } \\
\text { Product Data } \\
\text { Management } \\
\text { (p. 23). }\end{array}$ \\
\hline Ganton Technologies & $\begin{array}{l}\text { Sturtevant, } \\
\text { WI }\end{array}$ & $\begin{array}{l}\text { Supplier of die-case components to the automotive } \\
\text { industry. }\end{array}$ & $\begin{array}{l}\text { STEP Imple- } \\
\text { mentation Pro- } \\
\text { totypes (p. 35). }\end{array}$ \\
\hline $\begin{array}{l}\text { General Dynamics Land Sys- } \\
\text { tems Division }\end{array}$ & $\begin{array}{l}\text { Sterling } \\
\text { Heights, } \\
\text { MI }\end{array}$ & $\begin{array}{l}\text { Designs, manufactures, and supports armored weapon } \\
\text { systems and electronic products for the U.S. Army, the } \\
\text { U.S. Marine Corps and a number of allied nations. }\end{array}$ & $\begin{array}{l}\text { STEP Imple- } \\
\text { mentation Pro- } \\
\text { totypes (p. 35). }\end{array}$ \\
\hline $\begin{array}{l}\text { General Motors Corporation } \\
\text { Truck Division }\end{array}$ & $\begin{array}{l}\text { Pontiac, } \\
\text { MI }\end{array}$ & Automobile manufacturer. & $\begin{array}{l}\text { STEP Imple- } \\
\text { mentation Pro- } \\
\text { totypes (p. 35). }\end{array}$ \\
\hline
\end{tabular}




\section{References}

\begin{tabular}{|c|c|c|c|}
\hline \multicolumn{4}{|c|}{ Individual Companies } \\
\hline Name & Location & Description & $\begin{array}{l}\text { Collaborating } \\
\text { Project }\end{array}$ \\
\hline Industrial Technology Institute & $\begin{array}{l}\text { Ann } \\
\text { Arbor, MI }\end{array}$ & $\begin{array}{l}\text { Provider of services and applied research supporting } \\
\text { manufacturers. }\end{array}$ & $\begin{array}{l}\text { Application } \\
\text { Protocol Devel- } \\
\text { opment Envi- } \\
\text { ronment } \\
\text { (APDE) (p. 30). } \\
\text { STEP Conform- } \\
\text { ance Testing (p. } \\
\text { 33). } \\
\text { STEP Imple- } \\
\text { mentation Pro- } \\
\text { totypes (p. 35). }\end{array}$ \\
\hline $\begin{array}{l}\text { Institute of Advanced Manu- } \\
\text { facturing Sciences (IAMS) }\end{array}$ & $\begin{array}{l}\text { Cincinnati, } \\
\mathrm{OH}\end{array}$ & Vendor of computer-aided process planning software. & $\begin{array}{l}\text { Process Plan- } \\
\text { ning Applica- } \\
\text { tions (p. 20). }\end{array}$ \\
\hline $\begin{array}{l}\text { Isothermal Systems Research, } \\
\text { Inc. }\end{array}$ & $\begin{array}{l}\text { Colton, } \\
\text { WA }\end{array}$ & $\begin{array}{l}\text { Developer of thermal management systems for elec- } \\
\text { tronic systems. }\end{array}$ & $\begin{array}{l}\text { Information } \\
\text { Protocols for } \\
\text { Design (p. 15). }\end{array}$ \\
\hline ITW Deltar & $\begin{array}{l}\text { Mokena, } \\
\text { IL }\end{array}$ & Automotive parts supplier. & $\begin{array}{l}\text { STEP Imple- } \\
\text { mentation Pro- } \\
\text { totypes (p. } 35 \text { ). }\end{array}$ \\
\hline Kearfott, Inc. & Totowa, NJ & Automotive parts supplier. & $\begin{array}{l}\text { STEP Imple- } \\
\text { mentation Pro- } \\
\text { totypes (p. } 35 \text { ). }\end{array}$ \\
\hline Korry Electronics & $\begin{array}{l}\text { Seattle, } \\
\text { WA }\end{array}$ & $\begin{array}{l}\text { Manufacturer of electro-optical control and display com- } \\
\text { ponents and subsystems for the aerospace/defense mar- } \\
\text { kets. }\end{array}$ & $\begin{array}{l}\text { STEP Imple- } \\
\text { mentation Pro- } \\
\text { totypes (p. } 35 \text { ). }\end{array}$ \\
\hline McDonnell-Douglas & $\begin{array}{l}\text { St. Louis, } \\
\text { MO }\end{array}$ & Manufacturer of aerospace products. & $\begin{array}{l}\text { Production and } \\
\text { Product Data } \\
\text { Management } \\
\text { (p. } 23 \text { ). }\end{array}$ \\
\hline Nypro, Inc. & $\begin{array}{l}\text { Clinton, } \\
\text { MA }\end{array}$ & Supplier of molded plastic parts. & $\begin{array}{l}\text { STEP Imple- } \\
\text { mentation Pro- } \\
\text { totypes (p. } 35)\end{array}$ \\
\hline Pritsker Corporation & $\begin{array}{l}\text { West } \\
\text { Lafayette, } \\
\text { IN }\end{array}$ & Vendor of simulation and scheduling software. & $\begin{array}{l}\text { Production and } \\
\text { Product Data } \\
\text { Management } \\
\text { (p. 23). }\end{array}$ \\
\hline ProModel Corporation & Provo, UT & Vendor of simulation software. & $\begin{array}{l}\text { Production and } \\
\text { Product Data } \\
\text { Management } \\
\text { (p. 23). }\end{array}$ \\
\hline Shellcast & $\begin{array}{l}\text { Montreal, } \\
\text { CA }\end{array}$ & Supplier of die-cast components. & $\begin{array}{l}\text { STEP Imple- } \\
\text { mentation Pro- } \\
\text { totypes (p. } 35)\end{array}$ \\
\hline
\end{tabular}




\begin{tabular}{|c|c|c|c|}
\hline \multicolumn{4}{|c|}{ Individual Companies } \\
\hline Name & Location & Description & $\begin{array}{l}\text { Collaborating } \\
\text { Project }\end{array}$ \\
\hline SoftQuad, Inc. & $\begin{array}{l}\text { Toronto, } \\
\text { Canada }\end{array}$ & $\begin{array}{l}\text { Vendor of Standard Generalized Markup Language } \\
\text { (SGML) software tools. }\end{array}$ & $\begin{array}{l}\text { Application } \\
\text { Protocol Devel- } \\
\text { opment Envi- } \\
\text { ronment } \\
\text { (APDE) (p. 30). }\end{array}$ \\
\hline SPX Sealed Power Division & $\begin{array}{l}\text { Portage, } \\
\text { MI }\end{array}$ & $\begin{array}{l}\text { Manufacturer of piston rings and cylinder liners for the } \\
\text { automotive industry. }\end{array}$ & $\begin{array}{l}\text { STEP Imple- } \\
\text { mentation Pro- } \\
\text { totypes (p. 35). }\end{array}$ \\
\hline STEP Tools Inc. & Troy, NY & $\begin{array}{l}\text { Vendor of software tools that support the STEP (ISO } \\
\text { 10303) standard for data exchange and information mod- } \\
\text { eling. }\end{array}$ & $\begin{array}{l}\text { Application } \\
\text { Protocol Devel- } \\
\text { opment Envi- } \\
\text { ronment } \\
\text { (APDE) (p. 30). }\end{array}$ \\
\hline Team Science, Inc. & $\begin{array}{l}\text { Sudbury, } \\
\text { MA }\end{array}$ & $\begin{array}{l}\text { Consulting company specializing in development of } \\
\text { specifications for electronic data management. }\end{array}$ & $\begin{array}{l}\text { Standards for } \\
\text { Exchange of } \\
\text { Instrument } \\
\text { Data and NIST } \\
\text { Chemical Refer- } \\
\text { ence Data (p. } \\
40 \text { ). }\end{array}$ \\
\hline TRW & $\begin{array}{l}\text { Rogers- } \\
\text { ville, TN }\end{array}$ & $\begin{array}{l}\text { Major components supplier to automotive and aerospace } \\
\text { industries. }\end{array}$ & $\begin{array}{l}\text { STEP Imple- } \\
\text { mentation Pro- } \\
\text { totypes (p. } 35 \text { ). }\end{array}$ \\
\hline $\begin{array}{l}\text { United Defense Limited Part- } \\
\text { nership }\end{array}$ & York, PA & $\begin{array}{l}\text { Manufacturer of electronic systems for the defense } \\
\text { industry. }\end{array}$ & $\begin{array}{l}\text { STEP Imple- } \\
\text { mentation Pro- } \\
\text { totypes (p. } 35 \text { ). }\end{array}$ \\
\hline $\begin{array}{l}\text { Viewlogic Systems Incorpo- } \\
\text { rated }\end{array}$ & $\begin{array}{l}\text { Marlbor- } \\
\text { ough, MA }\end{array}$ & $\begin{array}{l}\text { Vendor of electronic product design and engineering } \\
\text { software. }\end{array}$ & $\begin{array}{l}\text { Electronic Com- } \\
\text { merce for the } \\
\text { Electronics } \\
\text { Industry } \\
\text { (ECCI) (p. 13). }\end{array}$ \\
\hline Wonderware, Inc. & Irving, $\mathrm{CA}$ & Vendor of shop floor data collection software. & $\begin{array}{l}\text { Production and } \\
\text { Product Data } \\
\text { Management } \\
\text { (p. 23). }\end{array}$ \\
\hline
\end{tabular}




\begin{tabular}{|c|c|c|c|}
\hline \multicolumn{4}{|c|}{ Government Agencies } \\
\hline Name & Location & Description & $\begin{array}{l}\text { Collaborating } \\
\text { Project }\end{array}$ \\
\hline $\begin{array}{l}\text { Defense Advanced Research } \\
\text { Projects Agency (DARPA) }\end{array}$ & $\begin{array}{l}\text { Arlington, } \\
\text { VA }\end{array}$ & $\begin{array}{l}\text { This Defense Department agency's primary mission is to } \\
\text { develop imaginative, innovative and often high risk } \\
\text { research ideas offering a significant technological impact } \\
\text { that will go well beyond the normal evolutionary devel- } \\
\text { opmental approaches; and, to pursue these ideas from } \\
\text { the demonstration of technical feasibility through the } \\
\text { development of prototype systems. }\end{array}$ & $\begin{array}{l}\text { Information } \\
\text { Protocols for } \\
\text { Design (p. 15). }\end{array}$ \\
\hline Defense Logistics Agency & $\begin{array}{l}\text { Fort Bel- } \\
\text { voir, VA }\end{array}$ & $\begin{array}{l}\text { This Defense Department agency provides supplies to } \\
\text { the military services and supports their acquisition of } \\
\text { weapons and other materiel. }\end{array}$ & $\begin{array}{l}\text { Apparel Infor- } \\
\text { mation Technol- } \\
\text { ogy (p. 12). }\end{array}$ \\
\hline $\begin{array}{l}\text { Los Alamos National Labora- } \\
\text { tory }\end{array}$ & $\begin{array}{l}\text { Los Ala- } \\
\text { mos, NM }\end{array}$ & $\begin{array}{l}\text { The Los Alamos National Laboratory is providing the } \\
\text { technical foundation to reduce the global nuclear danger } \\
\text { to ensure a more secure future for the nation. }\end{array}$ & $\begin{array}{l}\text { Standards for } \\
\text { Exchange of } \\
\text { Instrument } \\
\text { Data and NIST } \\
\text { Chemical Refer- } \\
\text { ence Data (p. } \\
40 \text { ). }\end{array}$ \\
\hline $\begin{array}{l}\text { National Research Institute for } \\
\text { Metals (NRIM) }\end{array}$ & $\begin{array}{l}\text { Tsukuba, } \\
\text { Japan }\end{array}$ & $\begin{array}{l}\text { NRIM has been devoted to the development and } \\
\text { improvement of new and advanced metallic materials. In } \\
\text { order to ensure the performance of existing materials } \\
\text { NRIM has been working on the establishment of the reli- } \\
\text { ability of materials, including research studies on the } \\
\text { prediction of the life span of materials. Furthermore, } \\
\text { NRIM is promoting various challenging research pro- } \\
\text { grams using high magnetic fields, ultra-high vacuum and } \\
\text { high energy beam assisted excited states. }\end{array}$ & $\begin{array}{l}\text { NIST Informat- } \\
\text { ics Web Site } \\
\text { Supporting } \\
\text { Advanced } \\
\text { Ceramics Appli- } \\
\text { cations (p. 40). }\end{array}$ \\
\hline Naval Research Laboratory & $\begin{array}{l}\text { Washing- } \\
\text { ton, DC }\end{array}$ & $\begin{array}{l}\text { The Naval Research Laboratory is the sponsoring } \\
\text { agency for the tri-service Microwave \& Millimeter-wave } \\
\text { Advanced Computational Environment (MMACE) Pro- } \\
\text { gram directed at the development of a comprehensive } \\
\text { computational design environment for microwave power } \\
\text { tubes. }\end{array}$ & $\begin{array}{l}\text { Electronic Com- } \\
\text { merce for the } \\
\text { Electronics } \\
\text { Industry } \\
(\mathrm{ECCI})(\mathrm{p} .13) .\end{array}$ \\
\hline $\begin{array}{l}\text { Pacific Northwest National } \\
\text { Laboratory }\end{array}$ & $\begin{array}{l}\text { Richland, } \\
\text { WA }\end{array}$ & $\begin{array}{l}\text { The Pacific Northwest National Laboratory's core mis- } \\
\text { sion is to deliver environmental science and technology. }\end{array}$ & $\begin{array}{l}\text { Online Access } \\
\text { to NIST Chemi- } \\
\text { cal Reference } \\
\text { Data (p. 40). }\end{array}$ \\
\hline
\end{tabular}




\begin{tabular}{|c|c|c|c|}
\hline \multicolumn{4}{|c|}{ Academic Institutions } \\
\hline Name & Location & Department & $\begin{array}{l}\text { Collaborating } \\
\text { Project }\end{array}$ \\
\hline $\begin{array}{c}\text { Brigham Young University } \\
\text {. }\end{array}$ & Provo, UT & Department of Manufacturing Engineering & $\begin{array}{l}\text { Production and } \\
\text { Product Data } \\
\text { Management } \\
\text { (p. 23). }\end{array}$ \\
\hline $\begin{array}{l}\text { California Polytechnic Univer- } \\
\text { sity }\end{array}$ & $\begin{array}{l}\text { Pomona, } \\
\text { CA }\end{array}$ & Business School & $\begin{array}{l}\text { Production and } \\
\text { Product Data } \\
\text { Management } \\
\text { (p. 23). }\end{array}$ \\
\hline Carnegie Mellon University & $\begin{array}{l}\text { Pittsburgh, } \\
\text { PA }\end{array}$ & $\begin{array}{l}\text { Software Engineering Institute (A federally funded } \\
\text { research and development center operated by CMU to } \\
\text { provide leadership in software engineering and in the } \\
\text { transition of new software engineering technology into } \\
\text { practice.) }\end{array}$ & $\begin{array}{l}\text { Framework (p. } \\
17) .\end{array}$ \\
\hline Carnegie Mellon University & $\begin{array}{l}\text { Pittsburgh, } \\
\text { PA }\end{array}$ & Department of Civil Engineering & $\begin{array}{l}\text { Process Plant } \\
\text { Engineering } \\
\text { and Construc- } \\
\text { tion (p. 22). }\end{array}$ \\
\hline Catholic University & $\begin{array}{l}\text { Washing- } \\
\text { ton, DC }\end{array}$ & Department of Mechanical Engineering & $\begin{array}{l}\text { Reference } \\
\text { Model Architec- } \\
\text { ture (p. 26). }\end{array}$ \\
\hline Drexel University & $\begin{array}{l}\text { Philadel- } \\
\text { phia, PA }\end{array}$ & Department of Electrical and Computer Engineering & $\begin{array}{l}\text { Reference } \\
\text { Model Architec- } \\
\text { ture (p. 26). }\end{array}$ \\
\hline George Washington University & $\begin{array}{l}\text { Washing- } \\
\text { ton, DC }\end{array}$ & Department of Engineering Management & $\begin{array}{l}\text { Process Plan- } \\
\text { ning Applica- } \\
\text { tions (p. } 20 \text { ). }\end{array}$ \\
\hline Harvard University & $\begin{array}{l}\text { Cam- } \\
\text { bridge, MA }\end{array}$ & Harvard Smithsonian Center for Astrophysics & $\begin{array}{l}\text { Integration of } \\
\text { NIST Standard } \\
\text { Reference Data } \\
\text { into Informa- } \\
\text { tion Networks } \\
\text { (p. 39). }\end{array}$ \\
\hline $\begin{array}{l}\text { Michigan Technological Uni- } \\
\text { versity }\end{array}$ & $\begin{array}{l}\text { Houghton, } \\
\text { MI }\end{array}$ & Department of Mechanical Engineering & $\begin{array}{l}\text { Production and } \\
\text { Product Data } \\
\text { Management } \\
\text { (p. 23). }\end{array}$ \\
\hline Northeastern University & $\begin{array}{l}\text { Boston, } \\
\text { MA }\end{array}$ & Industrial and Manufacturing Engineering & $\begin{array}{l}\text { Production and } \\
\text { Product Data } \\
\text { Management } \\
\text { (p. 23). }\end{array}$ \\
\hline Ohio University & $\begin{array}{l}\text { Athens, } \\
\mathrm{OH}\end{array}$ & Department of Industrial and Systems Engineering & $\begin{array}{l}\text { Production and } \\
\text { Product Data } \\
\text { Management } \\
\text { (p. } 23 \text { ). }\end{array}$ \\
\hline
\end{tabular}




\begin{tabular}{|c|c|c|c|}
\hline \multicolumn{4}{|c|}{ Academic Institutions } \\
\hline Name & Location & Department & $\begin{array}{l}\text { Collaborating } \\
\text { Project }\end{array}$ \\
\hline Purdue University & $\begin{array}{l}\text { West } \\
\text { Lafayette, } \\
\text { IN }\end{array}$ & Department of Industrial Engineering & $\begin{array}{l}\text { Production and } \\
\text { Product Data } \\
\text { Management } \\
\text { (p. 23). }\end{array}$ \\
\hline Purdue University & $\begin{array}{l}\text { West } \\
\text { Lafayette, } \\
\text { IN }\end{array}$ & Department of Computer Science & $\begin{array}{l}\text { Information } \\
\text { Protocols for } \\
\text { Design (p. 15). }\end{array}$ \\
\hline Stanford University & $\begin{array}{l}\text { Palo Alto, } \\
\text { CA }\end{array}$ & Knowledge Systems Laboratory & $\begin{array}{l}\text { Information } \\
\text { Protocols for } \\
\text { Design (p. 15). }\end{array}$ \\
\hline University of Illinois & $\begin{array}{l}\text { Chicago, } \\
\text { IL }\end{array}$ & Department of Computer Science & $\begin{array}{l}\text { Operator Inter- } \\
\text { faces for Virtual } \\
\text { and Distributed } \\
\text { Manufacturing } \\
\text { (p. 19). }\end{array}$ \\
\hline University of Maryland & $\begin{array}{l}\text { College } \\
\text { Park, MD }\end{array}$ & Department of Civil Engineering & $\begin{array}{l}\text { Process Plant } \\
\text { Engineering } \\
\text { and Construc- } \\
\text { tion (p. 22). }\end{array}$ \\
\hline University of Maryland & $\begin{array}{l}\text { College } \\
\text { Park, MD }\end{array}$ & Department of Computer Science & $\begin{array}{l}\text { Process Plan- } \\
\text { ning Applica- } \\
\text { tions (p. 20). } \\
\text { Production and } \\
\text { Product Data } \\
\text { Management } \\
\text { (p. 23). }\end{array}$ \\
\hline University of Maryland & $\begin{array}{l}\text { College } \\
\text { Park, MD }\end{array}$ & Department of Mechanical Engineering & $\begin{array}{l}\text { Information } \\
\text { Protocols for } \\
\text { Design (p. 15). } \\
\text { Process Plan- } \\
\text { ning Applica- } \\
\text { tions (p. 20). } \\
\text { Production and } \\
\text { Product Data } \\
\text { Management } \\
\text { (p. 23). }\end{array}$ \\
\hline $\begin{array}{l}\text { University of Maryland - Balti- } \\
\text { more County }\end{array}$ & $\begin{array}{l}\text { Catons- } \\
\text { ville, MD }\end{array}$ & Department of Chemistry & $\begin{array}{l}\text { Online Access } \\
\text { to NIST Chemi- } \\
\text { cal Reference } \\
\text { Data (p. } 40 \text { ). }\end{array}$ \\
\hline University of Tennessee & $\begin{array}{l}\text { Knoxville, } \\
\text { TN }\end{array}$ & Department of Chemistry & $\begin{array}{l}\text { Online Access } \\
\text { to NIST Chemi- } \\
\text { cal Reference } \\
\text { Data (p. } 40 \text { ). }\end{array}$ \\
\hline Washington State University & $\begin{array}{l}\text { Pullman, } \\
\text { WA }\end{array}$ & School of Mechanical and Materials Engineering & $\begin{array}{l}\text { Information } \\
\text { Protocols for } \\
\text { Design (p. 15). }\end{array}$ \\
\hline
\end{tabular}




\begin{tabular}{|l|l|l|l|}
\hline \multicolumn{2}{|c|}{ Academic Institutions } \\
\hline Name & Location & Department & $\begin{array}{l}\text { Collaborating } \\
\text { Project }\end{array}$ \\
\hline \hline Wiesbaden Polytechnic & $\begin{array}{l}\text { Wies- } \\
\text { baden, } \\
\text { Germany }\end{array}$ & Department of Computer Science & $\begin{array}{l}\text { Standards for } \\
\text { Exchange of } \\
\text { Instrument } \\
\text { Data and NIST } \\
\text { Chemical Refer- } \\
\text { ence Data (p. } \\
\text { 40). }\end{array}$ \\
\hline Virginia Polytechnic University & $\begin{array}{l}\text { Blacks- } \\
\text { burg, VA }\end{array}$ & Department of Industrial Engineering & $\begin{array}{l}\text { Production and } \\
\text { Product Data } \\
\text { Management } \\
\text { (p. 23). }\end{array}$ \\
\hline
\end{tabular}

\begin{tabular}{|c|c|c|c|}
\hline \multicolumn{4}{|c|}{ Standards Committees } \\
\hline Committee & Organization & Description & $\begin{array}{l}\text { Collaborating } \\
\text { Project }\end{array}$ \\
\hline $\begin{array}{l}\text { IEC/TC93/ } \\
\text { SC3D }\end{array}$ & $\begin{array}{l}\text { International Electrotechnical } \\
\text { Commission (IEC) }\end{array}$ & $\begin{array}{l}\text { The role of IEC/TC93/SC3D is to prepare standards } \\
\text { regarding methods and rules associated with the } \\
\text { handling of information in computer-sensible form. } \\
\text { This includes definition of data element types and } \\
\text { data sets for use in information models and techni- } \\
\text { cal documentation, and for exchange of technical } \\
\text { information. }\end{array}$ & $\begin{array}{l}\text { Electronic Com- } \\
\text { merce for the } \\
\text { Electronics } \\
\text { Industry } \\
\text { (ECCI) (p. 13). }\end{array}$ \\
\hline IEC/TC93/WG1 & $\begin{array}{l}\text { International Electrotechnical } \\
\text { Commission (IEC) }\end{array}$ & $\begin{array}{l}\text { The role of IEC/TC } 93 / \text { WG } 1 \text { is definition of meth- } \\
\text { odologies and guidelines for determining the } \\
\text { interoperability between proposed new standards } \\
\text { that lie within the context of TC } 93 \text { and new stan- } \\
\text { dards. }\end{array}$ & $\begin{array}{l}\text { Electronic Com- } \\
\text { merce for the } \\
\text { Electronics } \\
\text { Industry } \\
\text { (ECCI) (p. 13). }\end{array}$ \\
\hline IEC/TC93/WG3 & $\begin{array}{l}\text { International Electrotechnical } \\
\text { Commission (IEC) }\end{array}$ & $\begin{array}{l}\text { The role of IEC/TC93/WG3 is the development of } \\
\text { design interchange standards in the domain of elec- } \\
\text { tronic and electrical design. Relevant standards sup- } \\
\text { port CAD to CAD information transfers and CAD } \\
\text { to CAM information transfers. }\end{array}$ & $\begin{array}{l}\text { Electronic Com- } \\
\text { merce for the } \\
\text { Electronics } \\
\text { Industry } \\
\text { (ECCI) (p. 13). }\end{array}$ \\
\hline IEC/TC93/WG5 & $\begin{array}{l}\text { International Electrotechnical } \\
\text { Commission (IEC) }\end{array}$ & $\begin{array}{l}\text { The role of IEC/TC93/WG5 is to define methodolo- } \\
\text { gies and/or guidelines for the conformance and cer- } \\
\text { tification testing of any product which implements } \\
\text { a TC93 standard. Its goal is to gather consensus } \\
\text { among the member countries as to the acceptance } \\
\text { procedures used for conformance and certification } \\
\text { testing of products. }\end{array}$ & $\begin{array}{l}\text { Electronic Com- } \\
\text { merce for the } \\
\text { Electronics } \\
\text { Industry } \\
\text { (ECCI) (p. 13). }\end{array}$ \\
\hline $\begin{array}{l}\text { TC184/SC4/ } \\
\text { WG3/ Ad Hoc } \\
\text { Committee on } \\
\text { Parametrics }\end{array}$ & $\begin{array}{l}\text { International Organization for } \\
\text { Standardization (ISO) }\end{array}$ & $\begin{array}{l}\text { The role of the Parametrics Committee is to deter- } \\
\text { mine the need for parametric representations in } \\
\text { STEP and related standards, and propose how tech- } \\
\text { niques and models may be changed to meet those } \\
\text { needs. }\end{array}$ & $\begin{array}{l}\text { Information } \\
\text { Protocols for } \\
\text { Design (p. 15). } \\
\text { Reference } \\
\text { Model Architec- } \\
\text { ture (p. 26). }\end{array}$ \\
\hline
\end{tabular}


References

\begin{tabular}{|c|c|c|c|}
\hline \multicolumn{4}{|c|}{ Standards Committees } \\
\hline Committee & Organization & Description & $\begin{array}{l}\text { Collaborating } \\
\text { Project }\end{array}$ \\
\hline $\begin{array}{l}\text { TC184/SC4/ } \\
\text { WG3/T7 }\end{array}$ & $\begin{array}{l}\text { International Organization for } \\
\text { Standardization (ISO) }\end{array}$ & $\begin{array}{l}\text { The role of the Mechanical Product Definition } \\
\text { Committee is to analyze, document, and model } \\
\text { information and data about mechanical products. }\end{array}$ & $\begin{array}{l}\text { Reference } \\
\text { Model Architec- } \\
\text { ture (p. 26). }\end{array}$ \\
\hline $\begin{array}{l}\text { TC184/SC4/ } \\
\text { WG3/T11 }\end{array}$ & $\begin{array}{l}\text { International Organization for } \\
\text { Standardization (ISO) }\end{array}$ & $\begin{array}{l}\text { The role of the Manufacturing Technology Com- } \\
\text { mittee is to identify and define the information nec- } \\
\text { essary to manufacture or facilitate the manufacture } \\
\text { of a component. }\end{array}$ & $\begin{array}{l}\text { Reference } \\
\text { Model Architec- } \\
\text { ture (p. 26). }\end{array}$ \\
\hline $\begin{array}{l}\text { TC184/SC4/ } \\
\text { WG3/T12 }\end{array}$ & $\begin{array}{l}\text { International Organization for } \\
\text { Standardization (ISO) }\end{array}$ & $\begin{array}{l}\text { The role of the Process Plant AP Planning Project } \\
\text { committee is to work with industry to define the } \\
\text { scope and coordinate the development of applica- } \\
\text { tion protocols for the process plant industries. }\end{array}$ & $\begin{array}{l}\text { STEP for the } \\
\text { Process Plant } \\
\text { Industries (p. } \\
\text { 28). }\end{array}$ \\
\hline $\begin{array}{l}\text { STEP Steering } \\
\text { Committee }\end{array}$ & $\begin{array}{l}\text { International Society of Mea- } \\
\text { surement and Control (ISA) }\end{array}$ & $\begin{array}{l}\text { To develop standards and recommended practices } \\
\text { for the measurement, instrumentation, and control } \\
\text { industry. }\end{array}$ & $\begin{array}{l}\text { STEP for the } \\
\text { Process Plant } \\
\text { Industries (p. } \\
\text { 28). }\end{array}$ \\
\hline
\end{tabular}




\section{Appendix C: FY96 Project Publications}

MSE2: Electronic Commerce for the Electronics Industry (ECCI), (p. 13)

[8] Stewart, S., St. Pierre, J., Brady, K., "Conformance Testing and Specification Management", NISTIR 5879, NIST, Gaithersburg, MD, September 1996.

MSE3: Information Protocols for Design, (p. 15)

[9] Pratt, M., "What are Feature Interactions?", Proceedings of the 1996 American Society of Mechanical Engineers Computers in Engineering Conference, Irvine, CA, September 1996.

[10] Pratt, M., "The STEP Standard and it's Extension to Cover Parametric Constraint-Based and Feature-Based Modeling, in Advances in Computer Aided Design", Proceedings of the Computer Aided Design CADEX '96 Conference, Institute of Electrical and Electronic Engineers, Computer Society Press, Hagenberg, Austria, September 1996.

MSE6: Process Planning Applications, (p. 20)

[11] Feng, S., "A Machining Process Planning Activity Model for System Integration," NISTIR 5808, NIST, Gaithersburg, MD, March 1996.

[12] Feng, S., Zhang, C., "An Architecture of Component - Based CAPP Systems for Agile Manufacturing," Proceedings of the 1996 NSF Design and Manufacturing Grantees Conference, February, 1996.

[13] Schlenoff, C., Knutilla, A, Ray, S., "Unified Process Specification Language: Requirements for Modeling Process", NISTIR 5910, NIST, Gaithersburg, MD, September 1996.

MSE8: Production and Product Data Management, (p. 23)

[14] Iuliano, M., "Overview of the Manufacturing Engineering Toolkit Prototype," NISTIR 5730, NIST, Gaithersburg, MD, October 1995.

[15] Jones, A., Riddick, F., Rabelo, L., "Development of a Predictive-Reactive Scheduler using Genetic Algorithms and a Simulation-Based Scheduling Package", Advanced Manufacturing Processes, Systems, and Technology 1996, Bradford, England, March 1996.

[16] Jones, A., Rabelo, L., Yih, Y., "Job Shop Scheduling”, Encyclopedia of Operations Research, Kluwer Academic Publications, Norwell, MA, June 1996.

[17] Jones, A., Iuliano, M., "Hierarchical Control in a Virtual Manufacturing Facility", IASTED Conference, Honolulu, Hawaii, August 1996.

[18] McLean, C., Leong, S., “Application of Simulation Tools in Manufacturing”, Proceedings of the Electrical Manufacturing Coil Winding Association Conference, Chicago, IL, September 1996.

[19] Riddick, F., Brown, A.W., and Judd, R.P., "Architectural Issues in the Design and Implementation of an Integrated Toolkit for Manufacturing Engineering," International Journal of Computer-Integrated Manufacturing, May, 1996

[20] Yih, Y., Rabelo, L., and Jones, A., "A Neural Network Based Cell Controller for Automated Manufacturing Cells," Proceedings of the Institute for Industrial Engineering Research Conference, Minneapolis, MN, May 1996.

MSE9: Reference Model Architecture, (p. 26)

[21] Huang, H., "An Architecture and a Methodology for Intelligent Control”, IEEE Expert, Vol. 11, No. 2, April 1996. 
MSE10: STEP for the Process Plant Industries, (p. 28)

[22] Palmer, M., "Plant Spatial Configuration Application Protocol, Version 1.0", NISTIR 5675, NIST, Gaithersburg, MD, June 1996.

[23] Palmer, M., "Validation Report for Application Protocol 227, Version 1.0", NISTIR 5875, NIST, Gaithersburg, MD, August 1996.

SDE1: Application Protocol Development Environment (APDE), (p. 30)

[24] Lubell, J., "The Application Protocol Information Base World Wide Web Gateway", NISTIR 5868, NIST, Gaithersburg, MD, July 1996.

SDE3: STEP Conformance Testing, (p. 33)

[25] Kindrick, J., Sauter, J. and Matthews, R., "Improving conformance and interoperability testing," ACM StandardView, Vol. 4, No. 1, March 1996.

SDE4: STEP Implementation Prototypes, (p. 35)

[26] Frechette, S., "Interoperability Requirements for Computer Aided Design Data Transfer in the Autostep Project", NISTIR 5844, NIST, Gaithersburg, MD, March 1996.

[27] Rosenfeld, D., "Exchange Procedures for Autostep Phase 2", NISTIR 5833, NIST, Gaithersburg, MD, April 1996.

[28] Wilson, P., "STEP Interoperability Methodology for Solids Data”, NISTIR 5794, NIST, Gaithersburg, MD, February 1996.

TTTE1: Advanced Manufacturing Systems and Networking Testbed, (p. 37)

[29] Steves, M., Libes, D., "Organization of MSID's On-Line information - Experience and Recommendations," NISTIR 5792, NIST, Gaithersburg, MD, 1996.

TTTE6: Standards for Exchange of Instrument Data and NIST Chemical Reference Data, (p. 40)

[30] Staab, T., "Design and Implementation of a High-Level Communication Protocol for the Integration of Analytical Instruments into an Automated Laboratory System", Diplomarbeit, Fachhochschule, Wiesbaden Fachdereich Informatic, April 1996. 


\section{Appendix D: Program Products Newly Available in FY96}

Standard Reference Databases ${ }^{2}$

[1] Fundamental Physical Constants, E. Richard Cohen and Barry N. Taylor, September 1996.

Values of the basic constants and conversion factors of physics and chemistry resulting from the 1986 leastsquares adjustment of the fundamental physical constants as published by the CODATA Task Group on Fundamental Constants and recommended for international use by CODATA.

http://www.physics.nist.gov/PhysRefData/codata86/codata86.html

[2] Bibliographic Database on Atomic Transition Probabilities, J. R. Fuhr and H. R. Felrice, (Updated and Expanded), July 1996.

An interactive database with references on atomic transition probabilities (oscillator strengths, line strengths, and radiative lifetimes). Both theoretical and experimental papers are listed.

http://www.physics.nist.gov/PhysRefData/fvalbib/reffrm0.html

[3] X-Ray Attenuation and Absorption for Materials of Dosimetric Interest, J. H. Hubbell and S. M. Seltzer, May 1996.

Tables and graphs of the photon mass attenuation coefficients and the mass energy-absorption coefficients from $1 \mathrm{keV}$ to $20 \mathrm{MeV}$ are presented for all of the elements $(\mathrm{Z}=1$ to 92$)$ and for 48 compounds and mixtures of radiological interest. These coefficients are basic quantities used in calculations of the penetration and the energy deposition by photons ( $\mathrm{x}$-ray, gamma-ray, bremsstrahlung) in biological, shielding, and other materials.

http://www.physics.nist.gov/PhysRefData/XrayMassCoef/cover.html

[4] Bibliography of Photon Attenuation Measurements, J. H. Hubbell, August 1996.

A bibliography of papers (1907-1995) reporting absolute measurements of photon (XUV, x-ray, gamma-ray, bremsstrahlung) total interaction cross sections or attenuation coefficients for the elements and some compounds used in a variety of medical, industrial, defense, and scientific applications. The energy range covered is from $10 \mathrm{eV}$ to $13.5 \mathrm{GeV}$.

http://www.physics.nist.gov/PhysRefData/photoncs/html/attencoef.html

[5] NIST Chemistry Webbook, Linstrom, P.J., Mallard, G.W., Stein, S.E., Liebman, J.F., Lias, S.G., Levin, R.D., August 1996.

The Chemistry WebBook, contains thermodynamic data on an extensive set of organic and small inorganic compounds (Enthalpy of formation, Heat capacity, Entropy) for over 5000 compounds. As well as a large set of ion-energetics data (Ionization potential, Appearance potential) for over 10000 compounds. You may search for data on specific compounds in the WebBook based on name, chemical formula or CAS registry number.

http://webbook.nist.gov/

2. More information on Standard Reference Data products can be found at http://www.nist.gov/srd/. 

